\title{
Acute myocardial infarction in young women: current perspectives
}

This article was published in the following Dove Press journal:

International Journal of Women's Health

\author{
Jaya Chandrasekhar ${ }^{1}$ \\ Amrita Gill',2 \\ Roxana Mehran' \\ 'Department of Cardiology, Icahn \\ School of Medicine at Mount Sinai, \\ New York, NY, ${ }^{2}$ Saint Louis University, \\ St Louis, MO, USA
}

\begin{abstract}
Acute myocardial infarction (AMI) is the leading cause of death in women worldwide. Every year, in the USA alone, more than 30,000 young women $<55$ years of age are hospitalized with AMI. In recent decades, the incidence of AMI is increasing in younger women in the context of increasing metabolic syndrome, diabetes mellitus, and non-traditional risk factors such as stress, anxiety, and depression. Although women are classically considered to present with atypical chest pain, several observational data confirm that men and women experience similar rates of chest pain, with some differences in intensity, duration, radiation, and the choice of descriptors. Women also experience more number of symptoms and more prodromal symptoms compared with men. Suboptimal awareness, sociocultural and financial reasons result in pre-hospital delays in women and lower rates of access to care with resulting undertreatment with guideline-directed therapies. Causes of AMI in young women include plaque-related MI, microvascular dysfunction or vasospasm, and spontaneous coronary artery dissection. Compared with men, women have greater in-hospital, early and late mortality, as a result of baseline comorbidities. Post-AMI women have lower referral to cardiac rehabilitation with more dropouts, lower levels of physical activity, and poorer improvements in health status compared with men, with higher inflammatory levels at 1-year from index presentation. Future strategies should focus on primary and secondary prevention, adherence, and post-AMI health-related quality of life. This review discusses the current evidence in the epidemiology, diagnosis, and treatment of AMI in young women.
\end{abstract}

Keywords: acute myocardial infarction, young women, sex differences, women's health

\section{Introduction}

Acute myocardial infarction (AMI) has historically been regarded as a man's disease, and for many years, women have been underdiagnosed and undertreated. Bernadine Healy, the erstwhile director of the US National Institutes of Health, classically referred to this as the Yentl syndrome, describing women who were not recognized as experiencing AMI unless they presented with male-pattern chest pain symptoms. ${ }^{1,2}$ Since that time, significant efforts from different stakeholder groups have culminated in greater awareness and improved measures to recognize and manage AMI and coronary artery disease (CAD) in women. Yet, as a consequence of contemporary lifestyles and increasing prevalence of obesity, the incidence of AMI continues to increase, particularly in young women, who comprise a special high-risk population. It is crucial for both physicians and young individuals to be aware of disease risk factors, as well as cardiovascular signs and symptoms, in order to mitigate symptom to presentation times, toward optimizing patient care. In the current review, we discuss temporal trends in the incidence of AMI, evolving risk factors, pathophysiology, and evidence from recent clinical studies with a focus on young women. Figure 1 illustrates
Correspondence: Roxana Mehran Department of Cardiology, The Zena and Michael A Wiener Cardiovascular Institute, The Icahn School of Medicine at Mount Sinai, One Gustave L Levy Place, Box 1030, New York, NY 10029-6574, USA

Email roxana.mehran@mountsinai.org (c)
hereby accept the Terms. Non-commercial uses of the work are permitted without any further permission from Dove Medical Press Limited, provided the work is properly attributed. For permission hereby accept the Terms. Non-commercial uses of the work are permitted without any further permission from Dove Medie
for commercial use of this work, please see paragraphs 4.2 and 5 of our Terms (https://www.dovepress.com/terms.php). 


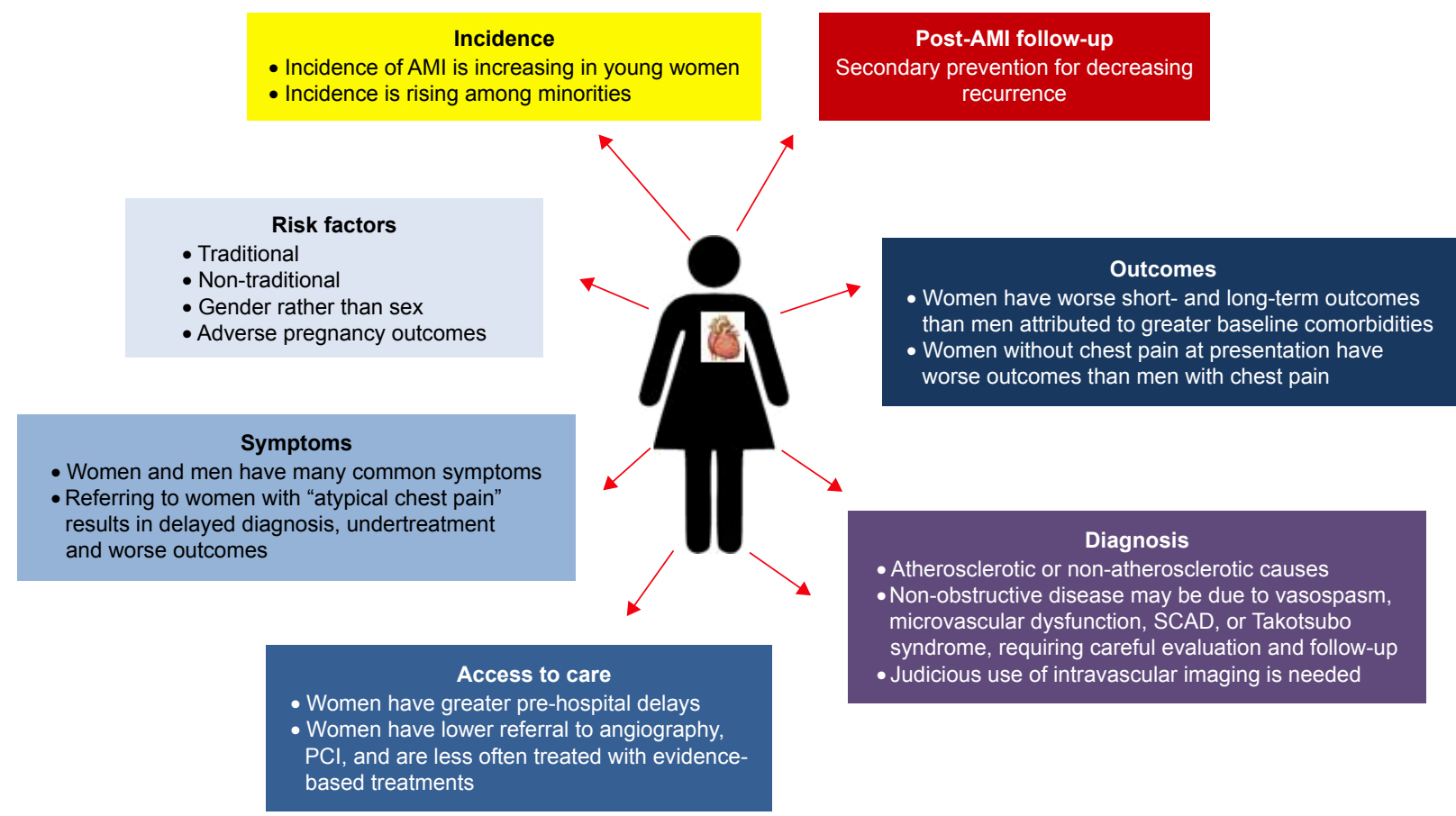

Figure I Current issues surrounding AMI management in young women.

Abbreviations: $\mathrm{AMI}$, acute myocardial infarction; $\mathrm{PCl}$, percutaneous coronary intervention; SCAD, spontaneous coronary artery dissection.

the comprehensive issues surrounding management of AMI in young women.

A few important studies specifically designed to examine female-specific risk factors and outcomes in ischemic heart disease (IHD) or AMI are worthy of mention..$^{3-5}$ These studies examined the role of female sex, gender, and non-traditional risk factors for AMI and CAD. The National Heart Lung and Blood Institute sponsored multicenter Women's Ischemia Evaluation (WISE) Study investigated the mechanisms of non-obstructive disease in women and the influence of reproductive hormones on the evaluation of IHD in women. ${ }^{3,6}$ The Variation in Recovery: Role of Gender on Outcomes of Young AMI Patients (VIRGO) study was a multicenter international observational study that compared young women between 30 and 55 years of age to young men enrolled at the time of AMI presentation (Table 1). ${ }^{4}$ The GENdEr and Sex determInantS of cardiovascular disease: from bench to beyond-Premature Acute Coronary SYndrome (GENESIS PRAXY) multicenter study was designed to examine outcomes in men and women between 18 and 55 years of age with premature acute coronary syndrome (ACS) in which gender-related characteristics were measured using a selfadministered questionnaire (Table 2). ${ }^{5,7}$

\section{Incidence of AMI}

The American Heart Association (AHA) Scientific Statement describes cardiovascular death as an equal opportunity killer, and while decline in AMI deaths has been noted in both men and women since the year 2000, rates are decreasing more so in men than in women. ${ }^{8}$ Talbott et al studied US Centers of Disease Control National Environmental Public Health Tracking Network data from 20 US participating states and showed that between 2000 and 2008, AMI rates decreased by $20 \%$ in men and in women. ${ }^{9}$ However, using data from the US National Inpatient Sample (NIS) from 1997 to 2006, Towfighi et al noted that MI hospitalization rates decreased over time by $26 \%$ in men but only $18 \%$ in women between the ages of 35 and 64 years. ${ }^{10}$ In fact, MI hospitalization rates increased for women 35-44 years and decreased only slightly for women 45-54 years and men 35-44 years. Recently, Izadnegahdar et al studied 70,628 AMI hospitalizations (17.1\% $\leq 55$ years of age) between 2000 and 2009 in British Columbia, Canada. ${ }^{11}$ Age-standardized AMI rates declined in men and women in similar manner; however, interaction was noted by age-sex-year with increasing rates noted only in younger women $(+1.7 \% /$ year). Younger women also continued to have higher mortality rates than younger men.

Recent data from the Agency for Healthcare Research and Quality's (AHRQ) Healthcare Cost and Utilization Project (HCUP)-NIS for the period 2001-2010 showed that in 230,684 patients between 30 and 54 years of age, overall, there was no increase in the incidence of AMI presentations in either sex over time. ${ }^{12}$ However, while women showed no change or increase in hospitalization 
Table I Important findings from the variation in recovery: role of gender on the outcomes of young AMI patients' study

\begin{tabular}{|c|c|c|}
\hline Author & Sample size & Key outcomes \\
\hline Spatz et a ${ }^{62}$ & $\mathrm{~N}=2,802$ & - One in eight women has an undetermined cause of $\mathrm{Ml}$, according to the third universal definition. \\
\hline Bucholz et al ${ }^{24}$ & $\begin{array}{l}N=3,50 \text { I } \\
(2,349 \text { women })\end{array}$ & $\begin{array}{l}\text { - Women have greater cardiovascular risk factors than men - including smoking, morbid obesity, diabetes, CHF, } \\
\text { COPD, renal failure, depression, stress, and lower quality of life at baseline. } \\
\text { - Women have higher clinical risk scores and pre-hospital delays; men have higher rise in biomarkers and more } \\
\text { classic ECG findings. } \\
\text { - Women were less likely to undergo primary reperfusion for STEMI. } \\
\text { - Women were less likely to undergo revascularization procedures than men. }\end{array}$ \\
\hline $\begin{array}{l}\text { Smolderen } \\
\text { et } \mathrm{al}^{26}\end{array}$ & $\begin{array}{l}\mathrm{N}=3,572 \\
(67 \% \text { women })\end{array}$ & $\begin{array}{l}\text { - At the time of AMI, more young women than men reported symptoms of depression ( } 39 \% \text { women vs } \\
22 \% \text { men). } \\
\text { - Lifetime history of depression was reported in } 48 \% \text { women vs } 24 \% \text { men. } \\
\text { - Patients with depression had higher stress, lower education, uninsured status, greater cardiovascular risks, and } \\
\text { worse quality of life. }\end{array}$ \\
\hline $\begin{array}{l}\text { Leifheit-Limson } \\
\text { et } \mathrm{al}^{49}\end{array}$ & $\begin{array}{l}N=3,501 \\
(2,349 \text { women })\end{array}$ & - Despite significant risk factors, only $50 \%$ of young AMI patients were aware of their risk prior to the event. \\
\hline $\begin{array}{l}\text { Smolderen } \\
\text { et } \mathrm{al}^{28}\end{array}$ & $\mathrm{~N}=3,324$ & $\begin{array}{l}\text { - Among patients with significant depression, only } 57.8 \% \text { received treatment. Male sex was an independent } \\
\text { predictor of not receiving treatment for depression. } \\
\text { - In } 68.3 \% \text { patients, depression resolved within I month. } \\
\text { - Patients who had persistent and untreated depression at I month had the lowest improvements in angina, } \\
\text { physical limitation, and both disease-specific and generic quality of life. }\end{array}$ \\
\hline Xu et $\mathrm{al}^{27}$ & $\begin{array}{l}N=3,509 \\
(2,358 \text { women })\end{array}$ & $\begin{array}{l}\text { - Women have higher levels of perceived stress at AMI presentation and throughout } 12 \text { months post-AMI. } \\
\text { - Stress levels changed similarly in women and men, decreasing over time and especially in the first month post-AMI. }\end{array}$ \\
\hline $\begin{array}{l}\text { D'Onofrio } \\
\text { et } \mathrm{al}^{49}\end{array}$ & $\begin{array}{l}N=I, 153 \\
(695 \text { women })\end{array}$ & $\begin{array}{l}\text { - Women have less reperfusion than men, particularly } \mathrm{PCl} \text { or fibrinolysis, due to presentation delays. } \\
\text { - More women were untreated than men }(9.0 \% \text { vs } 4.0 \%) \text {. } \\
\text { - There was no difference in reperfusion strategy between women and men. } \\
\text { - Women are more likely to exceed in-hospital and transfer time guidelines ( } 41 \% \text { women vs } 29 \% \text { men, OR I.65). } \\
\text { - Women are more likely to exceed door-to-needle times than men ( } 67 \% \text { vs } 37 \% \text {, OR } 2.62) \text {. }\end{array}$ \\
\hline Dreyer et al ${ }^{108}$ & $\begin{array}{l}N=3,50 \text { I } \\
(2,349 \text { women })\end{array}$ & $\begin{array}{l}\text { - Women have poorer pre-event health status: with lower generic and disease-specific health scores. } \\
\text { - Generic health scores were tested with Short form- } 12 \text { physical health and mental health questionnaire, } \\
\text { EuroQoL utility index, and visual analog scale. } \\
\text { - Disease-specific health status was tested with Seattle angina scores. }\end{array}$ \\
\hline
\end{tabular}

Follow-up

Lu et al"'I

$\mathrm{N}=2,985$ - More than $90 \%$ of women and men are discharged on statin after AMI.

(2,009 women); - Less than half of young AMI patients received a high intensity statin at discharge.

I month follow-up - Twelve percent patients stopped statin by I month follow-up.

in $\mathrm{N}=2,219$ - Although $\mathrm{LDL}$ reduced to $<100 \mathrm{mg} / \mathrm{dL}$ in both men and women, $\mathrm{HDL}$ remained $<40 \mathrm{mg} / \mathrm{dL}$ at I month.

( $\mathrm{I}, 424$ women)

Dreyer et al ${ }^{98} \quad \mathrm{~N}=3,50 \mathrm{I}$

(2,349 women)

Dreyer et a $\left.\right|^{99} \quad \mathrm{~N}=3,50 \mathrm{I} \quad$ - Young women were less likely to return to work than men after AMl (85\% vs $89 \%$ ).

(2,349 women) - Factors associated with returning to work were married status, clerical or professional type of work, better physical health, and absence of baseline hypertension or CAD.

Minges et al ${ }^{107} \quad \mathrm{~N}=3,466$

- Men were more active than women at baseline ( $42 \%$ vs $34 \%)$, I month ( $43 \%$ vs $34 \%$ ), and 12 months

(2,322 women)

( $48 \%$ vs $36 \%$ ) post-ACS, participating in guideline-directed exercise (moderate activity $\geq 150$ minutes per week or vigorous activity $\geq 75$ minutes per week).

- Men participated in longer duration of activity than women.

Lindau et $\mathrm{al}^{110} \quad \mathrm{~N}=3,50 \mathrm{I}$

- Few patients receive sexual health counseling after AMI. Patients are often provided incorrect advice not in (2,349 women) keeping with the guidelines.

Beckman $\quad \mathrm{N}=3,437$

et $\mathrm{al}^{112} \quad(2,306$ women $)$

- Financial barriers are common after AMI and associated with worse I-year outcomes.

- More women than men have financial barriers for medications (22.3\% vs $17.2 \%$; adjusted HR I.23, $95 \% \mathrm{Cl}=|.0 \mathrm{I}-| .5 \mathrm{I})$.

- Women and men reported financial barriers equally to services (31.3\% vs $28.9 \%)$.

- Patients with financial barriers had worse mental function status, more depression, stress, and poor quality of life.

Bucholz et al ${ }^{109} \mathrm{~N}=3,432$

- Young women and men with AMI perceived similar levels of social support at baseline (low social support perceived by I in 5 men and women; $21.4 \%$ women vs $20.9 \%$ men).

(2,303 women)

- Low social support was associated with lower mental functioning, quality of life, and depressive symptoms at 12 months.

Abbreviations: ACS, acute coronary syndrome; AMI, acute myocardial infarction; CAD, coronary artery disease; CHF, coronary heart failure; ECG, electrocardiography; HDL, high-density lipoprotein; LDL, low-density lipoprotein; MI, myocardial infarction; PCl, percutaneous coronary intervention; STEMI, ST-segment elevation MI. 
Table 2 Important findings from the GENdEr and Sex determlnantS of cardiovascular disease: from bench to beyond-Premature Acute Coronary SYndrome study

\begin{tabular}{|c|c|c|}
\hline Author & Sample size & Key outcomes \\
\hline Pelletier et $\mathrm{al}^{45}$ & I, I 23 patients & $\begin{array}{l}\text { - Fewer young women than men received ECG or fibrinolysis within benchmark times. } \\
\text { - Women with STEMI were less likely to undergo reperfusion. } \\
\text { - Women with NSTEMI were less likely to undergo PCI. } \\
\text { - Absence of chest pain, anxiety, and increased number of risk factors were determinants of } \\
\text { poorer access to care. }\end{array}$ \\
\hline Choi et al ${ }^{29}$ & I,015 patients & $\begin{array}{l}\text { - Women had more traditional (diabetes, hypertension, dyslipidemia, smoking, and obesity) and } \\
\text { non-traditional (anxiety, depression, and low household income) risk factors compared with men. } \\
\text { - However, median 10-year Framingham risk score was lower in women ( } 7 \% \text { vs I3\%) whereas } \\
30 \text {-year Framingham risk score was } 36 \% \text { in women and } 44 \% \text { in men. } \\
\text { - Consideration of non-traditional risk factors and } 30 \text {-year rather than } 10 \text {-year Framingham risk } \\
\text { might more accurately classify women. }\end{array}$ \\
\hline Pelletier et $\mathrm{al}^{94}$ & $\begin{array}{l}273 \text { women, } \\
636 \text { men }\end{array}$ & $\begin{array}{l}\text { - Female sex was not associated with increased risk of adverse outcomes. } \\
\text { - However, feminine roles and traits are associated with greater risk of recurrent ACS (HR 4.5, } \\
95 \% \mathrm{Cl}=1.05-19.27) \text { and a trend for greater MACE (HR I.54, } 95 \% \mathrm{Cl}=0.90-2.66) \text { than } \\
\text { masculine characteristics. } \\
\text { - When adjusted for increased anxiety, these associations were no longer significant. }\end{array}$ \\
\hline Afshar et al ${ }^{113}$ & $\begin{array}{l}939 \text { patients } \\
\text { (33.1\% women) }\end{array}$ & $\begin{array}{l}\text { - Lipoprotein (a) is associated with high LDL levels in young patients with ACS. } \\
\text { - Patients with high lipoprotein (a) and LDL levels }>3.5 \mathrm{mmol} \text { may warrant more aggressive lipid lowering. }\end{array}$ \\
\hline \multicolumn{3}{|l|}{ Follow-up } \\
\hline Leung-Yinko et al ${ }^{\prime 14}$ & 740 patients & $\begin{array}{l}\text { - Women and men with ACS had worse baseline health than the general population. At I year } \\
\text { post-ACS, only I\% more women and } 5 \% \text { more men reported intake } \geq 5 \text { daily servings of fruits } \\
\text { and vegetables, which was lower than in the general population. } \\
\text { - Women continued to smoke twice as often as men at I year. }\end{array}$ \\
\hline Leung-Yinko et al ${ }^{1 / 5}$ & & $\begin{array}{l}\text { - Gender-related factors such as social support but not sex influenced health-related quality of life } \\
\text { I year post-ACS. }\end{array}$ \\
\hline
\end{tabular}

Abbreviations: ACS, acute coronary syndrome; ECG, electrocardiography; LDL, low-density lipoprotein; MACE, major adverse cardiac events; MI, myocardial infarction; NSTEMI, non-STEMI; PCI, percutaneous coronary intervention; STEMI, ST-segment elevation MI.

rates for AMI, men showed decreases in hospitalization rates. Women comprised only $25.9 \%$ of all patients but more women than men were Black (19.7\% vs $10.5 \%)$. Black women in this analysis had higher hospitalization rates than White women, while rates were comparable for Black and White men. Further, Wang et al analyzed NIS data in the HCUP for patients between 2001 and 2007 across different age groups and also observed greater declines in MI hospitalization in White men and women $(30.8 \%$ and $31.4 \%$, respectively) compared with Black men and women (13.6\% and $12.6 \%$, respectively), regardless of age category. ${ }^{13}$

Yeh et al presented data from the California Kaiser Permanente system for MI hospitalizations between 1999 and 2008. ${ }^{14}$ Interestingly, the proportion of ST-segment elevation MI (STEMI) halved over this time; however, the age- and sex-adjusted incidence of Non-STEMIs (NSTEMI) increased. This was confirmed by other observational analyses, including a recent analysis from the ACTION (Acute Coronary Treatment and Intervention Outcomes Network) Get With The Guidelines database. ${ }^{15}$ Similarly, Zhang et al studied 77,943 Chinese AMI patients in Beijing between 2001 and 2012; AMI rates increased over time by $31.2 \%$ from 55.8 to 73.3 per
100,000 population. ${ }^{16}$ Although there was a decrease in STEMI, there was a threefold increase in the rate of NSTEMI.

\section{Prevalence of risk factors}

Studies have consistently shown than young women presenting with ACS have significantly greater comorbidities than young men, including smoking, diabetes, metabolic syndrome, hypertension, and chronic kidney disease. ${ }^{17-20}$ In the Providing Regional Observations to Study Predictors of Events in the Coronary Tree (PROSPECT) trial, 70.5\% women $<65$ years of age compared to $56.6 \%$ men $(p=0.02)$ reported history of smoking. ${ }^{20}$ Additionally, nearly two-thirds of women in this age group had metabolic syndrome at baseline ( $62.8 \%$ women vs $45.5 \%$ men, $p=0.004)$. In general, the prevalence of obesity and diabetes is increasing in US adults in both men and women. ${ }^{21}$ Even though the age-adjusted prevalence of metabolic syndrome has been reported to fall in women between 1999 and 2010 (with a peak in 2001-2002), there has been an increase in the prevalence of hypertriglyceridemia and increasing waist circumference attributed to decreasing physical activity, intake of fast food and sugar-sweetened beverages, and shorter sleep duration. ${ }^{22}$ 
While diabetes is considered a risk equalizer for overriding the benefits of estrogen in women, non-diabetic women have similar outcomes to diabetic men; thus, female sex itself lends risk equivalence to diabetes mellitus in men. ${ }^{23}$ Women with AMI also have greater prevalence of other comorbidities including congestive heart failure, chronic obstructive lung disease, and poor baseline mental health, with higher inflammatory markers than men. ${ }^{24}$ In one study, although women presented less often with STEMI than men ( $50 \%$ vs $57 \%, p=0.007$ ), they had higher rates of Global Registry of Acute Coronary Events (GRACE) score $\geq 140$ $(19 \%$ vs $12 \%, p=0.007) .{ }^{25}$

Young women also have greater prevalence of depression, anxiety, and stress, with higher depression and stress scores at the time of AMI presentation compared with men, as a function of greater comorbidities, familial conflict, financial concerns, and caregiving demands. ${ }^{8,17,26,27}$ Certainly, untreated depression in AMI patients is correlated with greater risk of 1-year mortality than patients with treated depression or patients without history of depression. ${ }^{28}$ In the GENESISPRAXY study, young women had greater traditional risk factors than young men, but also greater non-traditional risk factors such as anxiety, low household income, and depression (Figure 2). Use of 10-year Framingham risk score in this study did not correctly capture risk in young individuals, and the authors recommended that incorporation of non-traditional risk factors and consideration of 30-year Framingham risk score may more appropriately classify these patients. ${ }^{29}$ Further, from this study, female gender encompassing social and cultural factors, namely, stress level and responsibility at home, stress management, femininity score, primary earner status, number of hours worked per week, and social support, were observed to be more important than sex for health-related quality of life outcomes after ACS. ${ }^{30}$

Young women with history of adverse pregnancy outcomes are at higher risk of accelerated atherosclerosis and premature CAD. ${ }^{31}$ While premenopausal women are thought to be of low risk from a cardiovascular perspective due to the protective effects of estrogen, the higher rates of traditional cardiovascular risk factors outweigh these benefits. In the WISE study, premenopausal women with angiographic CAD had lower levels of estradiol than women without angiographic disease, and hypothalamic hypoestrogenemia was noted to be a multivariate predictor of outcomes. ${ }^{6}$ Premenopausal women may also be at higher risk of MI when estrogen level is low such as during the menstrual and follicular phases of the menstrual cycle. Indeed, higher levels of follicular-phase estrogen were associated with more favorable metabolic and hemostatic factors. ${ }^{32}$ Nevertheless, postmenopausal hormone replacement therapy, although shown to be beneficial in the Nurses' Health Study and the Danish Osteoporosis prevention study,,$^{33,34}$ has not proven to be of benefit in several randomized controlled trials. ${ }^{1,35-37}$

\section{Symptoms and signs}

Some studies have reported that more women commonly present with atypical right-sided chest pain, neck or shoulder

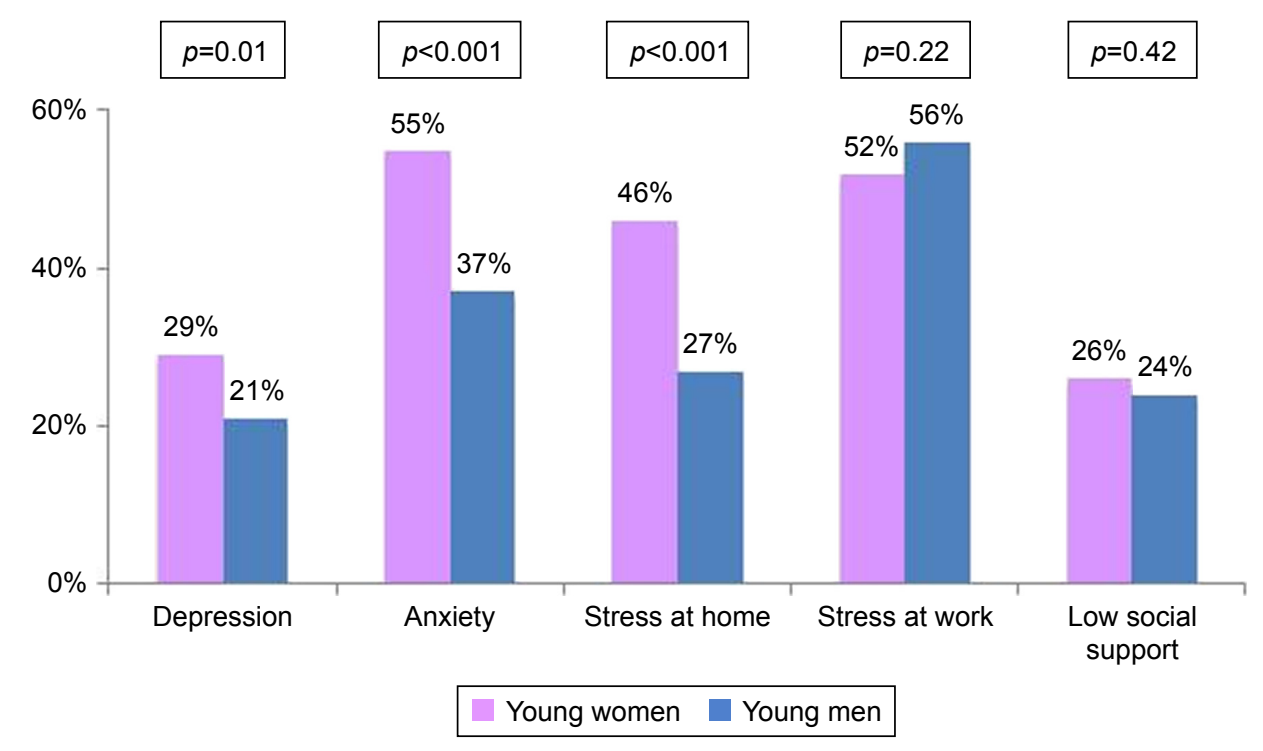

Figure 2 Sex differences in non-traditional risk factors among young AMI patients.

Note: Data taken from the GENESIS-PRAXY study, Choi et al. ${ }^{29}$

Abbreviation: AMI, acute myocardial infarction. 
pain compared with men who experience typical left-sided chest pain radiating to the left shoulder and jaw. ${ }^{22}$ In a retrospective survey study conducted in 1,270 women, $96 \%$ of women documented prodromal symptoms at the time of ACS presentation, and unusual fatigue (73\%) and sleep disturbance (50\%) were the most common symptoms. ${ }^{7}$ In the GENESISPRAXY study, ${ }^{38}$ women reported more prodromal symptoms than men $(85 \%$ vs $79 \%, p<0.001)$ and a greater number of symptoms (6 vs 4, $p<0.001$ ) including fatigue, sleep disturbances, anxiety, and arm weakness or discomfort.

However, from the Advantageous Predictors of Acute Coronary Syndrome Evaluation multinational registry ( $n=2,475,32.2 \%$ women), investigators noted that out of 34 chest pain characteristics, 29 were similar in men and women. ${ }^{39}$ Differences were observed only in chest pain radiation, intensity, and duration. Women more commonly reported radiation to the back and pain lasting for more than 30 minutes. Minority women reported more acute symptoms, albeit the symptoms differed by race (28\% Hispanics, $38 \%$ Blacks, and $42 \%$ Whites reported no chest pain or discomfort). Eastwood et al found that Blacks experienced more stomach-related symptoms rather than chest-related symptoms, which were observed in Caucasians. ${ }^{40}$

Other studies have also shown that men and women experience a majority of similar symptoms. ${ }^{41}$ Kreatsoulas et al showed that both sexes experienced chest pain equally, although women twice as often used the terms "discomfort", "crushing", "pressing", and "bad ache" compared to men. ${ }^{42}$ Men and women equally reported pain in the arms, back, and shoulders, and there were no sex differences in non-chest pain symptoms such as shortness of breath, fatigue, sweating, and weakness, but women more often experienced a dry mouth than men. In a study of 736 (37\% women) ACS patients presenting to the emergency department, shoulder and arm pain were predictive of ACS in both men and women. However, the predictive value of shoulder (OR 2.53; 95\% CI $=1.29-4.96$ ) and arm pain (OR 2.15; 95\% CI $=1.10-4.20)$ in women was nearly twice that of men (OR $1.11 ; 95 \% \mathrm{CI}=0.67-1.85$ and OR $1.21 ; 95 \% \mathrm{CI}=0.74-1.99) .{ }^{43}$

In an analysis of more than 1.1 million AMI patients from the National Registry of Myocardial Infarction between 1994 and 2006, Canto et al showed that although, overall, young women were less likely to present with chest pain than men, ${ }^{44}$ young men and older patients also presented without chest pain. Further, compared with younger women, older women were more likely to present without chest pain. Even though women have had low symptom severity, the number of symptoms was high compared with men. Notwithstanding, women presenting without chest pain had greater mortality (Figure 3), which may be a function of delayed presentation, underdiagnosis, and undertreatment. The authors cautioned that labeling women with atypical chest pain can lead to poorer outcomes and that men and women had several common symptoms in ACS presentations. Similarly, in the GENESIS-PRAXY study, both men and women without chest pain had poorer access to care and worse outcomes. ${ }^{45}$

While women have delays in presentation and higher clinical risk scores, men have more classic electrocardiography findings, allowing faster access to care. ${ }^{24}$ Female gender is strongly correlated with delayed hospital arrival and symptom to balloon time in STEMI due to low awareness, sociocultural and financial reasons. ${ }^{8,22,46,47}$ In a qualitative

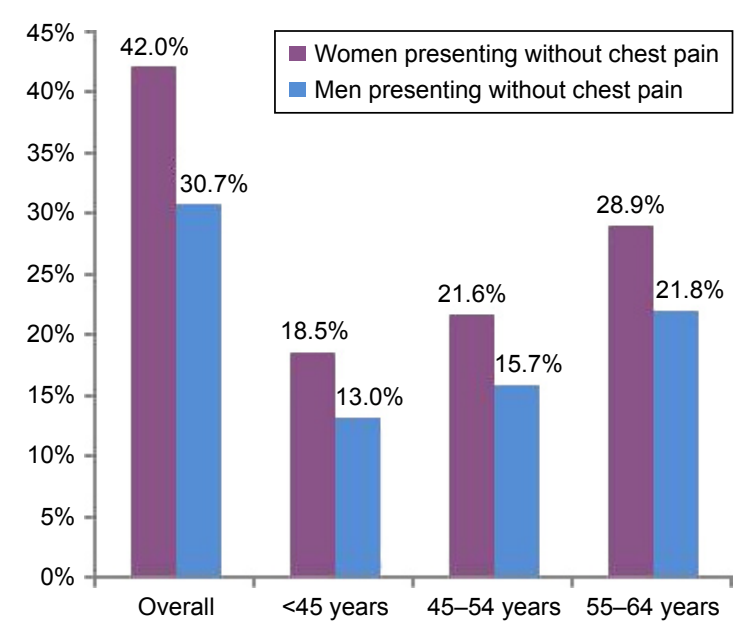

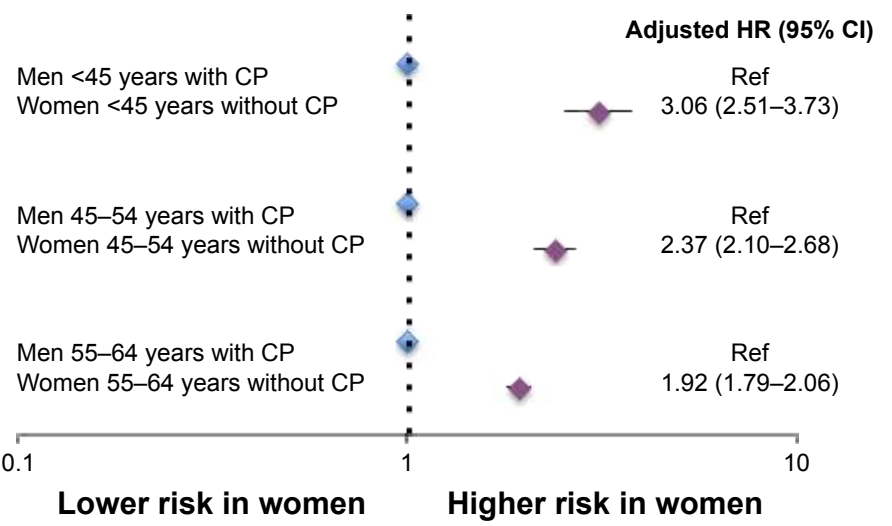

Figure 3 Sex differences in prevalence of non-chest pain AMI presentation in young adults, and associated risks in young women compared with men presenting with chest pain. Note: Data taken from Canto et al. ${ }^{44}$

Abbreviations: AMI, acute myocardial infarction; CP, chest pain; HR, hazard ratio. 
study of women between 30 and 55 years, authors noted that women were not accurately aware of their cardiovascular risks, reported poor preventative behaviors, and delayed seeking care for their symptoms. ${ }^{48}$ Despite significant risk factors, only one-half of men and women correctly perceived their risk of heart disease. ${ }^{49}$ Nevertheless, temporal analyses show that awareness has significantly increased among women; women also make greater use of ambulance services for medical assessment of chest pain. ${ }^{8,50}$ In the GENESISPRAXY study, young women were more likely to seek care than men ( $49 \%$ vs $42 \%, p=0.04)$, and among patients seeking care, women more often called for an ambulance $(52 \%$ vs $39 \%){ }^{38}$

\section{Pathophysiology}

Majority of AMI occur in the context of plaque rupture; however, in a third of cases, thrombus occurs with an intact fibrous cap. ${ }^{51}$ Virmani et al were the first to describe plaque erosions in the context of AMI, ${ }^{52}$ observing that premenopausal women had more plaque erosion compared with plaque rupture noted in postmenopausal women. On the other hand, coronary thrombosis in the setting of calcific nodules is more common in elderly women. Plaque erosion, associated with a thick-cap fibroatheroma, smooth muscle cells, greater proteoglycans, few macrophages, and inflammatory cells, is the cause of $25 \%-30 \%$ of STEMI cases, and younger smokers are more often affected. ${ }^{51}$ Different biomarkers may be implicated in plaque erosion and rupture, serving as useful targets for disease modulation. ${ }^{53}$ Recent studies have examined whether use of intravascular imaging with optical coherence tomography is useful in AMI patients to detect plaque erosion, which may allow a different treatment strategy avoiding stenting. ${ }^{54,55}$

\section{Angiographic characteristics and diagnostic dilemmas}

Women tend to have less adverse anatomical characteristics than men with lower plaque burden and less calcification, particularly among younger women. ${ }^{20,56,57}$ In the PROSPECT trial, there were no differences in culprit lesion number, location, or complexity by sex. Women tended to have more plaque erosion whereas men had plaque rupture. ${ }^{58}$ In nonculprit lesions, women $<65$ years had lower prevalence of plaque rupture $(1.2 \%$ vs $3.8 \%, p=0.01)$ and lower plaque volumes $(46.8 \%$ vs $47.7 \%, p=0.04)$ than men. ${ }^{17}$ In both men and women in this study, non-culprit lesions were not significantly associated with long-term major adverse cardiovascular events. ${ }^{59}$
However, invasive angiography may be inaccurate, and intravascular imaging is often required to confirm the presence and extent of plaque. From the WISE trial, $80 \%$ of patients with normal coronaries on angiography were observed to have plaque in the coronaries on intravascular ultrasound. ${ }^{60}$ In a study by Reynolds et al ( $n=50$ women), women with $<50 \%$ angiographic stenosis often had evidence of plaque disruption on intravascular ultrasound (39\% cases) and abnormal findings on cardiac magnetic resonance imaging (MRI; 59\% cases). ${ }^{61}$

In a VIRGO sub-study, patients were grouped according to the type of MI using the third universal definition; ${ }^{62}$ while most patients had plaque-related MI (82.5\% women, $94.9 \%$ men), other types included obstructive disease with ( $1.4 \%$ women; $0.9 \%$ men) and without $(2.4 \%$ women; $1.1 \%$ men) supply demand mismatch, non-obstructive disease with (4.3\% women; $0.8 \%$ men) and without supply demand mismatch (7.0\% women; $1.9 \%$ men), other mechanisms for MI (1.5\% women, $0.2 \%$ men), and unexplained MI ( $0.8 \%$ women, $0.2 \%$ men). The authors concluded that 1 in 8 women has an undetermined cause of MI necessitating better understanding of disease mechanisms for improved prognosis.

\section{Non-obstructive disease}

Women have a high prevalence of non-obstructive disease on angiography. ${ }^{63-65}$ Chest pain and AMI in the absence of atherosclerotic or obstructive coronary disease may be due to several reasons including coronary vasospasm, microvascular ischemia, spontaneous coronary artery dissection (SCAD), and stress cardiomyopathy. Myocardial infarction with normal coronary arteries (MINOCA) tends to affect young women and includes both endothelial dysfunction and vasospasm in the epicardial vessels and endothelial dysfunction in the microvasculature. ${ }^{65}$ Various descriptors have been used for this scenario including, syndrome $\mathrm{X}$, vasotonic angina, sensitive heart, angina with normal coronary arteries, microvascular angina, non-obstructive CAD, or the overlapping term INOCA (ischemia and no-obstructive coronary artery disease). ${ }^{65,66}$

Table 3 summarizes some clinical studies examining prevalence, sex differences, and outcomes in ACS patients with non-obstructive disease. ${ }^{67-73}$ Although prevalence varies from $6 \%$ to $30 \%$ in women with ACS and outcomes are generally better than with obstructive disease, it is not a benign condition, and therefore, deserves careful evaluation. In the WISE study, the incidence of non-obstructive disease with core laboratory-assessed angiographic stenosis between 20\% and $50 \%$ was quite common, occurring in $25 \%$ of women; 
Table 3 Clinical studies of ACS patients with non-obstructive disease

\begin{tabular}{|c|c|c|c|c|}
\hline Author & Study period & Data source & Sample size & Key outcomes \\
\hline $\begin{array}{l}\text { De Ferrari } \\
\text { et al }{ }^{67}\end{array}$ & 2014 & $\begin{array}{l}\text { Patient-level meta-analysis } \\
\text { from eight RCTs: GUSTO } \\
\text { Ilb, PURSUIT, PARAGON } \\
\text { A, PARAGON B, } \\
\text { SYNERGY, PRISM, PRISM- } \\
\text { PLUS, and EARLY ACS }\end{array}$ & 37,101 patients & $\begin{array}{l}\text { - Women with non-obstructive disease were younger with } \\
\text { lower prevalence of DM, prior } \mathrm{MI} \text { or } \mathrm{PCl} \\
\text { - Patients with non-obstructive disease had lower } 30 \text {-day and } \\
\text { I-year mortality compared with patients with obstructive } \\
\text { disease }\end{array}$ \\
\hline $\begin{array}{l}\text { Pasupathy } \\
\text { et al }{ }^{68}\end{array}$ & 2016 & Systematic review & $\begin{array}{l}28 \text { studies for } \\
\text { quantitative assessment; } \\
46 \text { studies for } \\
\text { qualitative assessment }\end{array}$ & $\begin{array}{l}\text { - Prevalence of MINOCA was } 6 \% \\
\text { - Compared with MI-CAD, MINOCA patients were likely to } \\
\text { be younger women but had similar risk factors } \\
\text { - One-year all cause mortality was lower in MINOCA vs } \\
\text { MI-CAD ( } 4.7 \% \text { vs } 6.7 \%) \\
\text { - MRI in MINOCA patients showed infarct in } 24 \% \text {, myocarditis } \\
\text { in } 33 \% \text {, and no abnormalities in } 26 \% \text {. Thrombophilia was } \\
\text { noted in } 14 \% \text { and coronary spasm was inducible in } 27 \%\end{array}$ \\
\hline Pizzi et al ${ }^{69}$ & $\begin{array}{l}\text { Data until } \\
\text { June } 30,2015\end{array}$ & $\begin{array}{l}\text { Systematic review and } \\
\text { meta-analysis }\end{array}$ & $\begin{array}{l}33 \text { studies, } \\
\text { 120,548 patients }\end{array}$ & $\begin{array}{l}\text { - Patients with non-obstructive disease have fewer risk factors } \\
\text { than those with obstructive disease } \\
\text { - They were more likely to be younger, female, with lower } \\
\text { prevalence of diabetes, hypertension, and dyslipidemia } \\
\text { - They have lower risk of future events, but not a benign } \\
\text { prognosis. Yearly rates of death ( } 2.4 \%) \text { and MI (I.6\%) were } \\
\text { lower in non-obstructive disease than in obstructive disease } \\
\text { (death } 10.1 \%, \mathrm{MI} 6.0 \% \text { ) }\end{array}$ \\
\hline $\begin{array}{l}\text { Johnston } \\
\text { et } \mathrm{al}^{70}\end{array}$ & $2005-2010$ & $\begin{array}{l}\text { SCAAR, Swedish } \\
\text { Coronary Angiography } \\
\text { and Angioplasty Registry }\end{array}$ & 95,849 patients & $\begin{array}{l}\text { - Non-obstructive disease has a prevalence of } 7 \% \text { in } \\
\text { STEMI (6\% in men, } 10 \% \text { in women) and I } 7 \% \text { in NSTEMI } \\
\text { (II\% in men, } 28 \% \text { in women) } \\
\text { - It is more common in women than in men } \\
\text { - Non-obstructive disease was associated with higher risk of } \\
\text { events in STEMI rather than in NSTEMI, during a median } \\
\text { follow-up of } 2.6 \text { years }\end{array}$ \\
\hline $\begin{array}{l}\text { Hansen } \\
\text { et } \mathrm{al}^{71}\end{array}$ & 2005-2007 & Danish registry data & $\begin{array}{l}20,800 \text { AMI patients, } \\
834 \text { women and } 76 \mathrm{I} \\
\text { men without significant } \\
\text { stenoses on angiography } \\
\text { who were discharged } \\
\text { and alive after } 60 \text { days }\end{array}$ & $\begin{array}{l}\text { - More women than men have non-obstructive disease } \\
\text { - There were no sex differences in discharge medications } \\
\text { among patients with non-obstructive disease } \\
\text { - Women and men have similar outcomes with } \\
\text { non-obstructive disease }\end{array}$ \\
\hline $\begin{array}{l}\text { Chokshi } \\
\text { et } \mathrm{al}^{72}\end{array}$ & $\begin{array}{l}\text { May to } \\
\text { September } 2006\end{array}$ & Two-center registry & 518 patients & 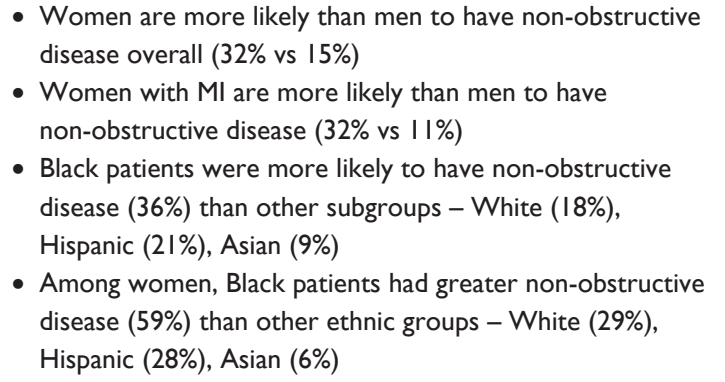 \\
\hline $\begin{array}{l}\text { Gehrie } \\
\text { et } \mathrm{al}^{73}\end{array}$ & $200 \mathrm{I}-2005$ & CRUSADE registry & $\begin{array}{l}4,903 \text { patients with } \\
\text { non-obstructive disease, } \\
2,282 \text { women }\end{array}$ & $\begin{array}{l}\text { - Non-obstructive disease was noted in } 9.5 \% ; 60 \% \text { were } \\
\text { women } \\
\text { - More than } 50 \% \text { NSTEMI patients with non-obstructive } \\
\text { disease had troponin values }>5 \text { upper limit of normal }(58.9 \% \\
\text { women vs } 58.6 \% \text { men) } \\
\text { - } 89 \% \text { women vs } 87 \% \text { men had positive TNI values despite } \\
\text { non-obstructive disease } \\
\text { - Females with non-obstructive disease were older than males } \\
\text { with greater risk factors } \\
\text { - Males and females with non-obstructive disease had similar } \\
\text { rates of in-hospital death, reinfarction, and other clinical } \\
\text { outcomes }\end{array}$ \\
\hline
\end{tabular}

Abbreviations: ACS, acute coronary syndrome; AMI, acute myocardial infarction; CAD, coronary artery disease; DM, diabetes mellitus; MI, myocardial infarction; MINOCA, myocardial infarction with normal coronary arteries; MRI, magnetic resonance imaging; NSTEMI, non-STEMI; PCI, percutaneous coronary intervention; RCT, randomized controlled trial; STEMI, ST-segment elevation MI; TNI, troponin I. 
no disease occurred in $37 \%$ and obstructive disease was present in $38 \% .{ }^{63}$ Ten-year cardiovascular death or MI occurred in $6.7 \%, 12.8 \%$, and $25.9 \%$ of patients with no disease, non-obstructive disease, and obstructive CAD. Jespersen et al noted that two-thirds of women undergoing coronary angiography for stable angina, compared with men, had non-obstructive $\mathrm{CAD} .{ }^{64}$ Both diffuse non-obstructive disease (HR $1.85,95 \% \mathrm{CI}=1.51-2.28$ ) and angiographically normal coronaries (HR 1.52, 95\% CI $=1.27-1.83$ ) were associated with greater risk of major adverse cardiac events (MACE) compared to an asymptomatic reference population.

\section{Microvascular dysfunction and coronary vasospasm}

Nearly two-thirds of women with non-obstructive disease may have evidence of microvascular dysfunction. ${ }^{74}$ The cause for coronary microvascular dysfunction (CMD) may be epicardial abnormal vasomotion or endothelial microvascular dysfunction, atherosclerotic emboli or inflammation. ${ }^{66,75}$ CMD has been noted both in the presence and in the absence of traditional cardiovascular risk factors. ${ }^{75}$ Microvascular ischemia can be objectively tested using echo Doppler, positron emission tomography, cardiac MRI, or invasive assessment of coronary flow reserve (CFR). ${ }^{66,75}$ In the recent white paper on INOCA, Bairey Merz et al summarize clinical studies testing for microvascular dysfunction in stable angina. ${ }^{66}$

Treatment for suspected microvascular ischemia includes calcium channel blockers and nitrates. ${ }^{66}$ Statins, angiotensinconverting enzyme inhibitors, and amitriptyline may be beneficial via a vasodilatory action. While smaller studies have shown that ranolazine increases CFR, it has not been shown to decrease clinical events in a randomized controlled trial. In the WISE study, low CFR was associated with greater circulating progenitor cells suggesting that chronic ischemia stimulates release and circulation of progenitor cells. ${ }^{76}$ This finding requires further examination as a potential biomarker for targeted treatment.

Coronary vasospasm, variant or Prinzmetal's angina, is caused by vagal withdrawal or increase in sympathetic drive, albeit other mechanisms may play a role such as decrease in nitric oxide, increase in phospholipase $\mathrm{C}$, or magnesium deficiency. ${ }^{65,77}$ It is common in young patients and smokers and frequently associated with ST-segment elevation or ventricular arrhythmias, but may also be caused by ingestion of recreational drugs (cocaine, cannabis, and amphetamines) or chemotherapy, antibiotics, and anti-migraine medications. ${ }^{77}$ Studies are conflicting on prevalence by sex - some studies have shown it is more common in women. ${ }^{78,79}$ In one study, outcomes were worst in young females presenting with coronary vasospasm. ${ }^{80}$ Treatment includes calcium channel blockers and nitrates. Statins are anti-inflammatory and may be beneficial through inhibition of rho-associated kinase. ${ }^{77}$

\section{Spontaneous coronary artery dissection}

SCAD is defined as a tear or separation in the layers of the coronary artery wall between the intima and the media, which is spontaneous and may be associated with intramural hemorrhage ${ }^{81}$ Majority of patients tend to be young women in the peripartum period, although an association has also been observed with fibromuscular dysplasia, with a SCAD prevalence of $25 \%-86 \%$ in this subset. ${ }^{82}$ Presentation is commonly with STEMI and may be associated with ventricular arrhythmias or sudden cardiac death. ${ }^{83,84}$ Although different angiographic types have been recognized, currently, the term SCAD is used to refer only to non-atherosclerotic variants of the disease. ${ }^{81}$ Diagnosis may be facilitated by the use of intravascular imaging. ${ }^{83}$ Treatment tends to be conservative rather than coronary stenting for risk of extending the dissection flap, but is dependent on the individual clinical setting. However, recurrence has been noted in up to $13 \%-17 \%$ of patients; ${ }^{82,84}$ hence, follow-up is crucial. SCAD is also associated with a high prevalence of anxiety and depression, particularly among young women and those with peripartum SCAD.$^{82,85}$ Thus, dedicated follow-up and rehabilitation can assist in early recognition for channeling appropriate specialist care ${ }^{86,87}$ After the initial diagnosis of SCAD, computed tomography angiography may be useful in patients with recurrent chest pain or to monitor for lesion healing. ${ }^{83}$ Recently, the Mayo clinic Virtual SCAD registry compared 54 pregnancy-related SCAD (P-SCAD, during pregnancy or within 12 weeks postpartum) patients with 269 non-pregnancy-related patients and noted that P-SCAD patients had more acute presentations and high-risk features such as STEMI, left main and/or multivessel SCAD, or reduced left ventricular function. ${ }^{88}$ Over a median follow-up of 2.3 years, there was no statistically significant difference in recurrence rates $(10 \%$ vs $23 \%, p=0.18)$.

\section{Stress cardiomyopathy}

Takotsubo (stress) cardiomyopathy is a left ventricular apical ballooning syndrome, triggered by emotional or physical stress and noted more often in older postmenopausal women, commonly presenting as ACS or STEMI in the absence of obstructive coronary disease. ${ }^{89}$ In a large international registry, the mean age of women presenting with Takotsubo syndrome was $66.8 \pm 13$ years, but men compared with women experienced worse short- and long-term mortality ${ }^{89}$ Some reports indicate that this condition may also be noted 
in younger patients suggesting that physicians should remain vigilant when other causes for MI have been excluded. ${ }^{90}$

\section{Pregnancy-related complications and premature atherosclerosis}

Pregnancy-related complications such as gestational diabetes, gestational hypertension, preeclampsia, low birthweight, and preterm labor are associated with endothelial dysfunction, metabolic derangements, and premature atherosclerosis contributing to future risk of cardiovascular events. ${ }^{31}$ Similarly, infertility and high parity are associated with greater risks, although precise mechanisms are unclear. ${ }^{91}$ It is crucial to manage cardiovascular risk early in these women through specialist cardiology referral organized by the obstetrician or general practitioner.

\section{Clinical outcomes}

Based on pooled data for the period 1995-2010 from the Framingham Heart Study, Multi-Ethnic Study of Atherosclerosis, Atherosclerosis Risk In Communities, and Coronary Artery Risk Development in Young Adults, the 2016 Heart and Stroke Statistics update reported that for patients between 45 and 64 years of age, within 1 year of first MI, 3\% White men, 5\% White women, 9\% Black men, and 10\% Black women will die. ${ }^{22}$ Tables 4 and 5 summarize key findings from selected clinical studies. With respect to temporal trends, Gupta et al showed from the AHRQ HCUP NIS that between 2001 and 2010, young women $<55$ years of age had longer in-hospital stay and greater in-hospital mortality than young men. ${ }^{12}$ Nevertheless, over time, women showed a $30.6 \%$ decrease in in-hospital mortality $(3.3 \%$ to $2.3 \%$, $p$-trend $<0.001)$, whereas rates were stable for men $(8.5 \%$ decrease, $2.0 \%-1.8 \%$, $p$-trend $=0.60$ ).

Several data have shown that young women have worse long-term outcomes than men after ACS presentation, correlated with worse baseline risk factors. ${ }^{17-19,92}$ In the PROMETHEUS observational study, women $<55$ years of age undergoing ACS percutaneous coronary intervention (PCI) had significantly greater rates of 1-year MACE $(21.1 \%$ vs $16.2 \%, p<0.001)$ and clinically significant bleeding $(3.6 \%$ vs $2.2 \%, p=0.01)$ than men, but after adjustment for baseline differences, outcomes were similar (HR for MACE $1.13,95 \% \mathrm{CI}=0.94-1.36$ in women compared to men; HR for bleeding $1.31,95 \% \mathrm{CI}=0.85-2.04$ ) suggesting that unadjusted differences were not due to biological variances. ${ }^{19}$ In the HORIZONS AMI randomized trial, which included 3,602 STEMI patients (23.4\% women, $40 \%$ elderly women $\geq 70$ years), female sex was found to be an independent predictor of bleeding events (HR 1.81, 95\% CI $=1.41-2.33, p<0.001)$ but not MACE (HR 1.09, 95\% CI $=0.91-1.32, p=0.35)$, which may be linked with greater use of femoral access ( $\sim 94.0 \%)$ and glycoprotein $2 \mathrm{~b} 3 \mathrm{a}$ inhibitor use in this study. ${ }^{18}$ Similarly, in the TRANSLATE-ACS study, unadjusted but not adjusted 1-year MACE was higher in women undergoing ACS PCI (15.7\% vs 13.6\%, $p=0.02$; HR $0.98,95 \% \mathrm{CI}=0.83-1.15$ ). Conversely, despite adjustment, bleeding remained significantly greater for women (GUSTO bleeding $9.1 \%$ vs $5.7 \%$; HR 1.32, 95\% CI =1.27-1.56). ${ }^{17}$

However, yet other studies have found persistently greater risk attributed to women even after adjustment for potential confounders. Data from the NRMI registry on 1.1 million patients between 1994 and 2006 showed that women with AMI presenting without chest pain had higher in-hospital mortality than men $(14.6 \%$ vs $10.3 \%, p<0.001)$, albeit mortality risk decreased with increasing age. ${ }^{44}$ In a recent Canadian observational study for 23,473 ACS patients from 2008 to 2011, women had higher propensity-adjusted risk of 1 -year rate of death or recurrent ACS (13.0\% in women and $10.0 \%$ in men; HR $1.24,95 \% \mathrm{CI}=1.16-1.33) .{ }^{93}$ In contrast, revascularization outcomes were similar in women compared to men $(17.8 \%$ vs $16.9 \%$; HR $1.06,95 \% \mathrm{CI}=0.99-1.14)$. In an observational study of young ACS patients ( $<55$ years of age) from Israel, female sex was observed to be an independent predictor of in-hospital mortality (HR 4.1, 95\% $\mathrm{CI}=1.15-14.0)$, 30-day major adverse cardiac and cerebrovascular events (HR 2.1, 95\% CI =1.31-3.36), and 5-year mortality (HR 1.96, 95\% CI =1.3-2.8). ${ }^{25}$ Interestingly, investigators of the GENESIS PRAXY study noted that female gender but not female sex was associated with greater risks and 1-year adverse outcomes. ${ }^{94}$

Rodriguez et al studied racial and sex differences from 194,071 patients taken from the NIS database for the period 2009-2010. ${ }^{95}$ Among patients $<65$ years of age, Hispanic and Black women had longer length of stay than younger White men. After multivariable adjustment, young Hispanic women had greater risk of adverse events compared with White men (OR 1.5, 95\% CI =1.2-1.9). Younger Hispanic women had higher in-hospital mortality (3.7\%) compared with Black (3.1\%) and White young women (2.5\%). The recent PLATINUM DIVERSITY multicenter US study was specifically designed to analyze outcomes in women and minorities undergoing PCI who are underrepresented in PCI trials compared with White men. ${ }^{96}$ The authors noted that women and minorities had higher incidence of 1-year death or MI compared with White men, albeit MACE outcomes were similar. 
Table 4 Selected clinical studies of young women with AMI/ACS presentation

\begin{tabular}{|c|c|c|c|c|}
\hline Author & $\begin{array}{l}\text { Study } \\
\text { period }\end{array}$ & Data source & Sample size & Key outcomes \\
\hline Khera et al ${ }^{116}$ & 2004-201I & $\begin{array}{l}\text { United States } \\
\text { Nationwide inpatient } \\
\text { sample }\end{array}$ & $\begin{array}{l}632,930 \text { adults with } \\
\text { STEMI }<60 \text { years of } \\
\text { age, } 74.7 \% \text { White }\end{array}$ & $\begin{array}{l}\text { - Young women were less likely to present with STEMI ( } 38.4 \% \text { vs } 49.4 \% \\
\text { OR } 0.74,95 \% \mathrm{Cl}=0.73-0.75) \\
\text { - Women underwent less angiography than men at each time point } \\
\text { - Women underwent less reperfusion ( } 68.4 \% \text { vs } 76.7 \%, p<0.00 \text { I) with } \\
\mathrm{PCl}(\mathrm{OR} 0.74,95 \% \mathrm{Cl}=0.73-0.75) \text {, CABG }(6.1 \% \text { vs } 8.0 \%, \mathrm{OR} 0.6 \mathrm{I} \text {, } \\
95 \% \mathrm{Cl}=0.60-0.62) \text {, or thrombolysis ( } 4.2 \% \text { vs } 4.5 \% \text {, OR } 0.80 \text {, } \\
95 \% \mathrm{Cl}=0.78-0.82) \text { than men } \\
\text { - In-hospital mortality was greater in young women than in men } \\
\text { ( } 4.5 \% \text { vs } 3.0 \% \text {, OR I.II, } 95 \% \mathrm{Cl}=\mathrm{I} .07-\mathrm{I} . \mathrm{I} 5) \\
\text { - There was a decrease in STEMls over time with increase in NSTEMls } \\
(p<0.00 \mathrm{I})\end{array}$ \\
\hline Gupta et al' ${ }^{12}$ & $200 I-2010$ & $\begin{array}{l}\text { United States } \\
\text { Nationwide inpatient } \\
\text { sample }\end{array}$ & $\begin{array}{l}230,684 \text { young AMI } \\
\text { hospitalizations in } \\
\text { adults } 30-54 \text { years of } \\
\text { age ( } 25.9 \% \text { women) }\end{array}$ & $\begin{array}{l}\text { - Hospitalization rates for young adults did not decline over time } \\
\text { - There was no difference in hospitalization rates for AMI by sex in } \\
\text { patients }<55 \text { years of age } \\
\text { - Women had longer length of stay and greater in-hospital mortality } \\
\text { - In-hospital mortality declined over time by } 30.6 \% \text { in women }(3.3 \% \\
\text { to } 2.3 \%, p \text {-trend }<0.00 \text { I), but remained stable in men }(2.0 \% \text { to } 1.8 \% \text {, } \\
\text { - } \text {-trend }=0.60) \\
\text { - More women than men with ACS were Black ( } 19.7 \% \text { vs } 10.5 \%) \\
\text { - Black women had higher rates of hospitalization and comorbidities } \\
\text { than White women } \\
\text { - In-hospital mortality was higher in Blacks than in Whites, for both } \\
\text { men and women }\end{array}$ \\
\hline Canto et a $\left.\right|^{44}$ & 1994-2006 & NRMI & $\begin{array}{l}\text { I.I million } \\
\text { AMI patients } \\
\text { ( } 42.1 \% \text { women); } \\
66,540 \text { adults } \\
<45 \text { years; } \\
\text { I32,777 adults } \\
45-54 \text { years }\end{array}$ & $\begin{array}{l}\text { - More women than men presented without chest pain }(42.0 \% \text { vs } \\
30.7 \%, p<0.00 \mathrm{I}) \\
\text { - There was a larger sex difference in non-chest pain presentations in } \\
\text { younger than older adults ( } 15.3 \% \text { women vs } 10.2 \% \text { men }<45 \text { years; } \\
14.5 \% \text { women vs } 10.6 \% \text { men } 45-54 \text { years) } \\
\text { - Compared with young women, older women had more non- } \\
\text { chest pain presentations ( } 15.3 \% \text { in women }<45 \text { years, } 21.8 \% \text { in } \\
\text { women } \geq 75 \text { years) } \\
\text { - Women vs men had greater in-hospital mortality ( } 14.6 \% \text { vs } 10.3 \%) \\
\text { - Younger women presenting without chest pain had greater risk of } \\
\text { in-hospital mortality than young men; this risk decreased with age } \\
\text { - In women }<45 \text { years vs men: adjusted OR I.I8 (I.00-I.39) } \\
\text { - In women } 45-54 \text { years vs men: adjusted OR I.I3 (I.02-I.26) }\end{array}$ \\
\hline Epps et al ${ }^{117}$ & $1997-2006$ & $\begin{array}{l}\text { NHLBI Dynamic } \\
\text { registry }\end{array}$ & $\begin{array}{l}10,963 \mathrm{PCl} \text { patients } \\
(3,797 \text { women, } \\
394<50 \text { years })\end{array}$ & $\begin{array}{l}\text { - Compared with older women, younger women had higher rates of } \\
\text { I-year MACE ( } 27.8 \% \text { vs } 19.9 \% ; p=0.003) \text { due to greater TLF } \\
\text { - Compared with older women, younger women had higher } 5 \text {-year } \\
\text { rates of repeat procedures ( } 10.7 \% \text { vs } 6.8 \%, p=0.04) \\
\text { - Overall, women had worse outcomes than men } \\
\text { - Outcomes were similar in older women vs older men }\end{array}$ \\
\hline De Luca et al $^{118}$ & $200 I-20 I 4$ & $\begin{array}{l}\text { Five nationwide } \\
\text { pooled Italian } \\
\text { registries }\end{array}$ & $\begin{array}{l}\text { I3,235 patients, } 27.9 \% \\
\text { women; } 376 \text { women } \\
<55 \text { years; } 558 \text { women } \\
55-64 \text { years }\end{array}$ & $\begin{array}{l}\text { - In-hospital mortality increased with age. Female sex was an } \\
\text { independent predictor of in-hospital mortality (OR I.44, } \\
95 \% \mathrm{Cl}=1.07-1.93, p=0.009 \text { ) } \\
\text { - Rates of non-reperfusion in patients }<55 \text { years was } 19 \% \text { for women in } \\
2014 \text { compared with } 5 \% \text { men in the same age group. Primary } \mathrm{PCl} \text { was } \\
\text { used in } 66 \% \text { women vs } 83 \% \text { men in this age group } \\
\text { - For patients between } 55 \text { and } 64 \text { years, non-reperfusion rate was } 12 \% \\
\text { in women compared with } 8 \% \text { in men } \\
\text { - In-hospital mortality was low in men and women }<55 \text { years. In } \\
\text { patients between } 55 \text { and } 64 \text { years, in-hospital mortality occurred in } \\
3.4 \% \text { women vs I.3\% men. Rates of major bleeding were higher in } \\
\text { women than in men } \\
\text { - In-hospital mortality decreased over time in both men and women, } \\
\text { but less so in women }\end{array}$ \\
\hline
\end{tabular}


Table 4 (Continued)

\begin{tabular}{|c|c|c|c|c|}
\hline Author & $\begin{array}{l}\text { Study } \\
\text { period }\end{array}$ & Data source & Sample size & Key outcomes \\
\hline Udell et $\mathrm{al}^{93}$ & 2008-20II & $\begin{array}{l}\text { Ontario, Canada } \\
\text { registry }\end{array}$ & $\begin{array}{l}23,490 \text { ACS patients } \\
\text { (34.5\% women) }\end{array}$ & $\begin{array}{l}\text { - Women received less revascularization than men in the same } \\
\text { admission ( } 66.1 \% \text { vs } 5 \mathrm{I} .8 \%) \\
\text { - One-year death or ACS was higher in women (I3.1\% vs } 10.6 \% \text {, } \\
\text { propensity adjusted HR I.24, } 95 \% \mathrm{CI}=1.16-1.33)\end{array}$ \\
\hline $\begin{array}{l}\text { Izadnegahdar } \\
\text { et al'। }\end{array}$ & 2000-2009 & $\begin{array}{l}\text { British Columbia, } \\
\text { Canada ACS registry }\end{array}$ & $\begin{array}{l}70,628 \text { AMI patients; } \\
\text { I7.I\% } \leq 55 \text { years; } \\
\text { ( } 25.6 \% \text { women })\end{array}$ & $\begin{array}{l}\text { - AMI rates increased in younger women } \\
\text { - Over time, } 30 \text {-day mortality decreased similarly in men and women, } \\
\text { without evidence of interaction } \\
\text { - Young women had greater risk of } 30 \text {-day mortality in all time periods }\end{array}$ \\
\hline Heer et al ${ }^{119}$ & 2007-2009 & $\begin{array}{l}\text { German Society of } \\
\text { Cardiology registry }\end{array}$ & $\begin{array}{l}\text { I85,3 } 12 \mathrm{PCl} \text { patients; } \\
27.9 \% \text { women; } \\
5 \mathrm{I} .3 \% \mathrm{AMI}\end{array}$ & $\begin{array}{l}\text { - Women with STEMI had } 20 \% \text { greater age-adjusted risk of death than } \\
\text { men (OR I.I9, } 95 \% \mathrm{CI}=\mathrm{I} .06-\mathrm{I} .33) \\
\text { - Younger women with STEMI but not NSTEMI had higher rates of } \\
\text { in-hospital mortality than men }\end{array}$ \\
\hline Pelletier et $\mathrm{al}^{97}$ & 2009-2013 & $\begin{array}{l}\text { GENESIS-PRAXY } \\
\text { study }\end{array}$ & $\begin{array}{l}\text { Patients } 18-55 \text { years } \\
\text { of age ( } 273 \text { women, } \\
636 \text { men) }\end{array}$ & $\begin{array}{l}\text { - Female gender but not sex was an independent predictor of adverse } \\
\text { outcomes } \\
\text { - However, feminine roles and traits are associated with greater risk of } \\
\text { recurrent } \mathrm{ACS}(\mathrm{HR} 4.5,95 \% \mathrm{Cl}=\mathrm{I} .05-19.27) \text { and a trend for greater } \\
\text { MACE (HR I.54,95\% } \mathrm{Cl}=0.90-2.66) \text { than masculine characteristics } \\
\text { - When adjusted for increased anxiety, these associations were no } \\
\text { longer significant }\end{array}$ \\
\hline Sabbag et $\mathrm{al}^{25}$ & 2000-2013 & $\begin{array}{l}\text { Biennial Israeli ACS } \\
\text { survey database }\end{array}$ & $\begin{array}{l}\text { I I,536 ACS } \\
\text { patients }-3,949 \\
(34 \%) \leq 55 \text { years of } \\
\text { age; } 407 \text { women }\end{array}$ & $\begin{array}{l}\text { - Women presented less often with STEMI ( } 50 \% \text { vs } 57 \%) \\
\text { - Women presented less often with typical chest pain ( } 73 \% \text { vs } 80 \%) \\
\text { - More women had GRACE score } \geq I 40 \text { at presentation } \\
\text { - Even after adjustment for diabetes, GRACE score, and year of } \\
\text { enrolment, women underwent less revascularization than men } \\
\text { - Female sex was an independent predictor of } 30 \text {-day (HR 2.I, } \\
95 \% \mathrm{Cl}=\mathrm{I} .3 \mathrm{I}-3.36) \text { and } 5 \text {-year (HR I.96, } 95 \% \mathrm{Cl}=\mathrm{I} .30-2.80) \\
\text { mortality }\end{array}$ \\
\hline $\begin{array}{l}\text { Rodriguez } \\
\text { et } \mathrm{al}^{95}\end{array}$ & 2009-2010 & $\begin{array}{l}\text { National Inpatient } \\
\text { Sample }\end{array}$ & $\begin{array}{l}\text { I94,07I AMI patients; } \\
43 \% \text { patients } \\
<65 \text { years of age; } \\
\text { I7,455 White women, } \\
4,694 \text { Black women, } \\
2,116 \text { Hispanic women } \\
<65 \text { years of age }\end{array}$ & 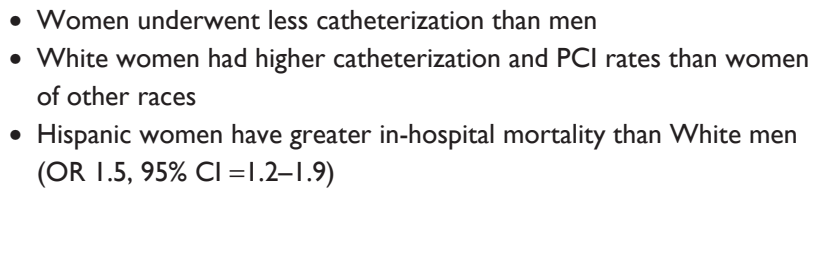 \\
\hline $\begin{array}{l}\text { Chandrasekhar } \\
\text { et } \mathrm{al}^{56}\end{array}$ & $2010-2013$ & $\begin{array}{l}\text { PROMETHEUS } \\
\text { multicenter US study }\end{array}$ & $\begin{array}{l}4,85 \text { I ACS patients } \\
\leq 55 \text { years of age, } \\
24.0 \% \text { women; } \\
54 \% \text { AMI, } 46 \% \\
\text { unstable angina }\end{array}$ & $\begin{array}{l}\text { - Women had similar adjusted risk of MACE and clinically significant } \\
\text { bleeding to men } \\
\text { - Prasugrel was used in fewer young women than men }(28.1 \% \text { vs } 31.8 \%) \\
\text { - Bivalirudin was used in fewer women than men }(28.0 \% \text { vs } 31.7 \%)\end{array}$ \\
\hline Redfors et al $^{92}$ & $1995-20 \mid 4$ & $\begin{array}{l}\text { Swedish Web System } \\
\text { for Enhancement of } \\
\text { Evidence-Based Care } \\
\text { in Heart Disease } \\
\text { Evaluated According } \\
\text { to Recommended } \\
\text { Therapies registry } \\
\text { (SWEDEHEART) }\end{array}$ & $\begin{array}{l}\text { 48, I I8 AMI patients } \\
\text { (35.4\% women) }\end{array}$ & $\begin{array}{l}\text { - Overall, women had better adjusted survival than men except for } \\
\text { younger women and women presenting with STEMI } \\
\text { - Younger women }<60 \text { years had higher mortality than men } \\
\text { - Women were less likely to be prescribed guideline therapies than men } \\
\text { - There were no changes in these trends over time }\end{array}$ \\
\hline
\end{tabular}

Abbreviations: ACS, acute coronary syndrome; AMI, acute myocardial infarction; CABG, coronary artery bypass grafting; MACE, major adverse cardiac events; MI, myocardial infarction; NHLBI, National Heart Lung and Blood Institute; NRMI, National Registry of Myocardial Infarction; NSTEMI, non-STEMI; PCl, percutaneous coronary intervention; STEMI, ST-segment elevation MI; TLF, target lesion failure.

Women with ACS have also been shown to have greater rehospitalization rates than men. In the GENESIS-PRAXY study, women had greater all-cause ( $13 \%$ vs $9 \%, p=0.006)$ but not cardiac rehospitalizations. ${ }^{97}$ Dreyer et al analyzed young patients aged 18-64 years with a principal diagnosis of AMI from the HCUP-State Inpatient Database for California
(2007-2009) and found that women were more likely than men to have increased 30-day readmissions (15.5\% vs 9.7\%, $p<0.0001$, adjusted hazard ratio, $1.22 ; 95 \% \mathrm{CI}=1.15-1.30) .{ }^{98}$ However, women more commonly than men had readmissions from non-cardiac reasons ( $44.4 \%$ vs $40.6 \%, p=0.01)$. In the TRIUMPH study, women had a $26 \%$ increase in 1-year 
Table 5 Clinical studies of AMI patients examining outcomes by race and sex

\begin{tabular}{|c|c|c|c|c|}
\hline Author & $\begin{array}{l}\text { Study } \\
\text { period }\end{array}$ & Data source & Sample size & Key outcomes \\
\hline $\begin{array}{l}\text { Gupta } \\
\text { et al }\end{array}$ & $200 \mathrm{I}-20 \mathrm{IO}$ & $\begin{array}{l}\text { United States } \\
\text { NIS }\end{array}$ & $\begin{array}{l}230,684 \text { young } \mathrm{AMI} \\
\text { hospitalizations in adults } \\
30-54 \text { years of age } \\
(25.9 \% \text { women })\end{array}$ & $\begin{array}{l}\text { - More women than men with ACS were Black (19.7\% vs } 10.5 \%) \\
\text { - Black women had higher rates of hospitalization and } \\
\text { comorbidities than White women } \\
\text { - In-hospital mortality was higher in Blacks than in Whites, both } \\
\text { for men and women }\end{array}$ \\
\hline $\begin{array}{l}\text { Wang } \\
\text { et } \mathrm{al}^{13}\end{array}$ & $200 \mathrm{I}-2007$ & $\begin{array}{l}\text { NIS from the } \\
\text { HCUP }\end{array}$ & $\begin{array}{l}2,179,509 \text { AMI } \\
\text { hospitalizations } \\
\text { (not restricted to } \\
\text { young AMI) }\end{array}$ & $\begin{array}{l}\text { - Greater declines were noted in age-adjusted AMI } \\
\text { hospitalization rates in White men and women ( } 30.8 \% \text { and } \\
31.4 \% \text {, respectively) compared with Black men and women } \\
\text { (13.6\% and } 12.6 \%) \text { over the study period }\end{array}$ \\
\hline $\begin{array}{l}\text { Rodriguez } \\
\text { et } \mathrm{al}^{95}\end{array}$ & 2009-2010 & NIS & $\begin{array}{l}\text { 194,07| AMI patients; } \\
43 \% \text { patients }<65 \text { years } \\
\text { of age; } \\
\text { 17,455 White women, } \\
4,694 \text { Black women, } \\
2,116 \text { Hispanic women } \\
<65 \text { years of age }\end{array}$ & $\begin{array}{l}\text { - Women underwent less catheterization than men } \\
\text { - White women had higher catheterization and } \mathrm{PCl} \text { rates than } \\
\text { women of other races } \\
\text { - Hispanic women had greater in-hospital mortality than White } \\
\text { men (OR } 1.5,95 \% \mathrm{Cl}=1.2-1.9)\end{array}$ \\
\hline $\begin{array}{l}\text { Edmund } \\
\text { Anstey } \\
\text { et } \text { al }^{15}\end{array}$ & 2008-20II & $\begin{array}{l}\text { ACTION } \\
\text { Registry Get } \\
\text { with the } \\
\text { guidelines } \\
\text { database }\end{array}$ & $\begin{array}{l}\text { I75,370 AMI patients } \\
\text { (STEMI: I8,77I White } \\
\text { women; 2,283 Black } \\
\text { women; NSTEMI: } 35,24 \text { I } \\
\text { White women; } 5,702 \\
\text { Black women); (not } \\
\text { restricted to young AMI) }\end{array}$ & $\begin{array}{l}\text { - Catheterization rates were similar by race for STEMI; Blacks } \\
\text { underwent less catheterization than Whites for NSTEMI } \\
\text { - Revascularization rates were lower for Blacks than Whites for } \\
\text { STEMI and NSTEMI } \\
\text { - Black women were less likely to undergo catheterization and } \\
\text { PCI than White women in low and intermediate ACTION risk } \\
\text { groups but not in high ACTION risk groups }\end{array}$ \\
\hline $\begin{array}{l}\text { Batchelor } \\
\text { et } \mathrm{al}^{96}\end{array}$ & $2011-2014$ & $\begin{array}{l}\text { PLATINUM } \\
\text { Diversity study } \\
\text { pooled with the } \\
\text { Premier Element } \\
\text { PAS cohort }\end{array}$ & $\begin{array}{l}4,188 \text { patients }(\mathrm{I}, 863 \\
\text { women, } 55 \% \text { ACS and } \\
\text { I,059 minorities, } 53 \% \\
\text { ACS); (not restricted to } \\
\text { young AMI) }\end{array}$ & $\begin{array}{l}\text { - Women and minorities were older with greater prevalence of } \\
\text { diabetes at baseline compared with White men } \\
\text { - Women and minorities had higher adjusted risk of I-year } \\
\text { death or Ml compared with White men } \\
\text { - Women and minorities were less likely to remain on dual } \\
\text { antiplatelet therapy at I year compared with White men }\end{array}$ \\
\hline
\end{tabular}

Abbreviations: ACS, acute coronary syndrome; ACTION, Acute Coronary Treatment and Intervention Outcomes Network; AMI, acute myocardial infarction; HCUP, Healthcare Cost and Utilization Project; MI, myocardial infarction; NIS, National Inpatient Sample; NSTEMI, non-STEMI; PAS, post approval study; PCI, percutaneous coronary intervention; STEMI, ST-segment elevation MI.

AMI rehospitalizations even after adjustment for clinical risks. ${ }^{99}$ However, after adjustment for health status and psychosocial factors, these differences were attenuated and no increased risk or interaction by sex was noted.

\section{Treatment bias}

A treatment bias has long been described for women presenting with AMI. Despite significantly higher risk of adverse events, women are less likely to be referred for cardiac catheterizations or PCI, due to underdiagnosis and perceived risk of complications. ${ }^{18,25,93,100}$ In the Canadian ACS study by Udell et al, $66.1 \%$ men and $51.8 \%$ women received cardiac catheterization in the same admission. ${ }^{93}$ In the Israeli ACS registry, even after adjustment for GRACE score, diabetes, and year of enrolment, young women $<55$ years of age were less likely to undergo in-hospital coronary angiography (OR 0.6, $p=0.007) .{ }^{25}$ In data from the Korean nationwide registry (Korea Working Group of Myocardial Infarction) between November 2005 and July 2011, women $\leq 50$ years of age were more likely to be treated with conservative management ( $30.4 \%$ vs $11.2 \%, p<0.001)$ and less likely to receive optimal medical therapy and less PCI $(69.5 \%$ vs $89 \%$, $p<0.001$ ) with lower rates of PCI success ( $85.8 \%$ vs $92.2 \%$, $p<0.001) .{ }^{100}$ In the GENESIS-PRAXY study, $13 \%$ women vs $3 \%$ men $(p=0.01)$ reported no intervention done. ${ }^{38}$ Rodriguez et al noted that among patients $<65$ years, women were less likely to undergo angiography and PCI than men among all races. Nevertheless, young White women had higher rates of angiography compared with women of other races..$^{95}$

Women are also less likely to receive evidence-based therapies than men. ${ }^{18,101}$ In the WISE study, during 1-year follow-up, women with non-obstructive disease were less likely to receive statins $(12 \%$ in women with no disease vs $33 \%$ in non-obstructive disease vs $53 \%$ in obstructive disease) and other medications compared with patients with obstructive disease. ${ }^{63}$ In the GENESIS-PRAXY study, use of cardiovascular risk reduction therapies was $\leq 40 \%$ in both men and women, and $<50 \%$ patients perceived that their provider attributed a cardiac cause for the presentation. ${ }^{38}$ In the PROMETHEUS study, prasugrel was less often used 
in young women than men $<55$ years of age $(28.1 \%$ vs $31.8 \%, p=0.01$ ), ostensibly due to greater perceived risk of bleeding; however, bivalirudin was also used less often in women $(28.0 \%$ vs $31.7 \%, p=0.016) .{ }^{19}$

Although this bias has decreased over the last couple of decades, there still remains a gap in the treatment of men and women. The exact reasons for this gap need to be explored in future studies but may include sociocultural reasons and delayed referrals in women. ${ }^{8}$

\section{Rehabilitation and health quality post-ACS}

Prior research has shown that women are less likely to be referred for cardiac rehabilitation than men, despite guideline recommendations. ${ }^{8}$ Some factors limiting attendance at rehabilitation might be depression, arthritis, distance from the hospital, and poor social support, which can be overcome by home- and community-based approaches. ${ }^{102}$ Cardiac rehabilitation dropout rates are highest in young women, with high depression and anxiety scores, even though rehabilitation and physical activity have been shown to alleviate depression. ${ }^{103}$ In a small randomized trial, dedicated rehabilitation with motivational interviewing was superior to traditional cardiac rehabilitation in women for reducing depressive symptoms. ${ }^{104}$ Contemporary approaches using digital health technology may be successfully used to encourage young patients to complete cardiac rehabilitation. ${ }^{105}$

In the GENESIS-PRAXY study, both baseline and 1-year health behavior profiles of young patients were worse than the general population, albeit small improvements noted at 1-year post-ACS. ${ }^{106}$ At baseline, men had lower intake of fruit and vegetables but greater alcohol and recreational drug consumption compared with women. At 1 -year post-ACS, only $5 \%$ more men and $1 \%$ more women consumed $\geq 5$ daily servings of fruit and vegetables. Women with ACS continued to smoke twice as much as the general population at 1-year post-ACS.

In the VIRGO study, Minges et al found that young men exercised more often than women at baseline ( $42 \%$ vs $34 \%$ ), 1 month (45\% vs 34\%), and 12 months (48\% vs 36\%) after ACS presentation ( $p<0.001$ for all) ${ }^{107}$ Even after adjustment for baseline confounders, young women were less likely to be active from baseline to 12 months (HR 1.37, 95\% $\mathrm{CI}=1.21-1.55)$. Women were also less likely to return to work than men ( $85 \%$ vs $89 \%, p=0.02)$, especially in occupations involving physical labor. ${ }^{108}$ Being married, engaged in a professional or clerical job, better physical health, and no previous CAD or hypertension were associated with higher likelihood of returning to work. Low perceived social support had a significant impact on health outcomes in young men and women after AMI. ${ }^{109}$
While fewer young women than men discuss risks and risk factor modification with their physicians, younger patients are also rarely given sexual counseling after AMI and are commonly given restrictions not based on guidelines. ${ }^{49,110}$

\section{Conclusion}

The incidence of AMI in young women is increasing in conjunction with increasing lifestyle risk factors and greater prevalence of diabetes, obesity, and metabolic syndrome. Risk factors are evolving and non-traditional risk factors such as depression, anxiety, and stress warrant careful consideration in clinical assessment. Non-atherosclerotic mechanisms of ACS should be evaluated in patients without obstructive disease, since non-diagnosis can result in high morbidity and healthcare costs. Along with improvements in symptom awareness of young women for early presentation, focus on secondary prevention with guideline-directed therapies is necessary to improve outcomes. Dedicated post-ACS care and rehabilitation may be tailored to patient needs to optimize long-term healthrelated quality of life.

\section{Disclosure}

The authors report no conflicts of interest in this work. Dr Mehran has received institutional grant support from Astra Zeneca, The Medicines Co., Bristol-Myers Squibb/Sanofi, and Eli Lilly and Company/Daiichi Sankyo. Dr Mehran is a consultant for AstraZeneca, Bayer, CSL Behring, Janssen Pharmaceuticals, Merck \& Co, The Medicines Co., and Watermark Consulting. She serves on the advisory board of Abbott Laboratories, AstraZeneca, Boston Scientific, Covidien, Janssen Pharmaceuticals, Merck \& Co., The Medicines Co., and Sanofi-Aventis and has equity in Claret Medical and Elixir Medical Corp. Dr Chandrasekhar and Ms Gill have no financial disclosures.

\section{References}

1. Herrington DM, Reboussin DM, Brosnihan KB, et al. Effects of estrogen replacement on the progression of coronary-artery atherosclerosis. $N E n g l$ J Med. 2000;343(8):522-529.

2. Healy B. The Yentl syndrome. N Engl J Med. 1991;325(4):274-276.

3. Merz CN, Kelsey SF, Pepine CJ, et al. The Women's Ischemia Syndrome Evaluation (WISE) study: protocol design, methodology and feasibility report. J Am Coll Cardiol. 1999;33(6):1453-1461.

4. Lichtman JH, Lorenze NP, D'Onofrio G, et al. Variation in recovery: role of gender on outcomes of young AMI patients (VIRGO) study design. Circ Cardiovasc Qual Outcomes. 2010;3(6):684-693.

5. Pilote L, Karp I. GENESIS-PRAXY (GENdEr and Sex determInantS of cardiovascular disease: From bench to beyond-Premature Acute Coronary SYndrome). Am Heart J. 2012;163(5):741-746.e2. 
6. Bairey Merz CN, Johnson BD, Sharaf BL, et al. Hypoestrogenemia of hypothalamic origin and coronary artery disease in premenopausal women: a report from the NHLBI-sponsored WISE study. J Am Coll Cardiol. 2003;41(3):413-419.

7. McSweeney JC, O'Sullivan P, Cleves MA, et al. Racial differences in women's prodromal and acute symptoms of myocardial infarction. Am J Crit Care. 2010;19(1):63-73.

8. Mehta LS, Beckie TM, DeVon HA, et al; American Heart Association Cardiovascular Disease in Women and Special Populations Committee of the Council on Clinical Cardiology, Council on Epidemiology and Prevention, Council on Cardiovascular and Stroke Nursing, and Council on Quality of Care and Outcomes Research. Acute myocardial infarction in women: a scientific statement from the American Heart Association. Circulation. 2016;133(9):916-947.

9. Talbott EO, Rager JR, Brink LL, et al. Trends in acute myocardial infarction hospitalization rates for US States in the CDC tracking network. PLoS One. 2013;8(5):e64457.

10. Towfighi A, Markovic D, Ovbiagele B. National gender-specific trends in myocardial infarction hospitalization rates among patients aged 35 to 64 years. Am J Cardiol. 2011;108(8):1102-1107.

11. Izadnegahdar M, Singer J, Lee MK, et al. Do younger women fare worse? Sex differences in acute myocardial infarction hospitalization and early mortality rates over ten years. $J$ Womens Health (Larchmt). 2014;23(1):10-17.

12. Gupta A, Wang Y, Spertus JA, et al. Trends in acute myocardial infarction in young patients and differences by sex and race, 2001 to 2010 . J Am Coll Cardiol. 2014;64(4):337-345.

13. Wang OJ, Wang Y, Chen J, Krumholz HM. Recent trends in hospitalization for acute myocardial infarction. Am J Cardiol. 2012;109(11): 1589-1593.

14. Yeh RW, Sidney S, Chandra M, Sorel M, Selby JV, Go AS. Population trends in the incidence and outcomes of acute myocardial infarction. N Engl J Med. 2010;362(23):2155-2165.

15. Edmund Anstey D, Li S, Thomas L, Wang TY, Wiviott SD. Race and sex differences in management and outcomes of patients after STElevation and Non-ST-Elevation Myocardial Infarct: results from the NCDR. Clin Cardiol. 2016;39(10):585-595.

16. Zhang Q, Zhao D, Xie W, et al. Recent trends in hospitalization for acute myocardial infarction in Beijing: increasing overall burden and a transition from ST-Segment Elevation to Non-ST-Segment elevation myocardial infarction in a population-based study. Medicine. 2016; 95(5):e2677.

17. Hess CN, McCoy LA, Duggirala HJ, et al. Sex-based differences in outcomes after percutaneous coronary intervention for acute myocardial infarction: a report from TRANSLATE-ACS. J Am Heart Assoc. 2014; 3(1):e000523.

18. Yu J, Mehran R, Grinfeld L, et al. Sex-based differences in bleeding and long term adverse events after percutaneous coronary intervention for acute myocardial infarction: three year results from the HORIZONS-AMI trial. Catheter Cardiovasc Interv. 2015;85(3): 359-368.

19. Chandrasekhar J, Baber U, Sartori S, et al. Sex-related differences in outcomes among men and women under 55 years of age with acute coronary syndrome undergoing percutaneous coronary intervention: Results from the PROMETHEUS study. Catheter Cardiovasc Interv. 2017;89(4):629-637.

20. Ruiz-Garcia J, Lerman A, Weisz G, et al. Age- and gender-related changes in plaque composition in patients with acute coronary syndrome: the PROSPECT study. Euro Intervention. 2012;8(8):929-938.

21. Menke A, Casagrande S, Geiss L, Cowie CC. Prevalence of and trends in diabetes among adults in the United States, 1988-2012. JAMA. 2015; 314(10):1021-1029.

22. Writing Group Members, Mozaffarian D, Benjamin EJ, et al. Heart disease and stroke statistics-2016 update: a report from the American Heart Association. Circulation. 2016;133(4):e38-e360.

23. Farhan S, Baber U, Vogel B, et al. Impact of diabetes mellitus on ischemic events in men and women after percutaneous coronary intervention. Am J Cardiol. 2017;119(8):1166-1172.
24. Bucholz EM, Strait KM, Dreyer RP, et al. Sex differences in young patients with acute myocardial infarction: a VIRGO study analysis. Eur Heart J Acute Cardiovasc Care. 2017;6(7):610-622.

25. Sabbag A, Matetzky S, Porter A, et al. Sex differences in the management and 5-year outcome of young patients $(<55$ Years $)$ with acute coronary syndromes. Am J Med. 2017;130(11):1324.e15-1324.e22.

26. Smolderen KG, Strait KM, Dreyer RP, et al. Depressive symptoms in younger women and men with acute myocardial infarction: insights from the VIRGO study. J Am Heart Assoc. 2015;4(4):e001424.

27. Xu X, Bao H, Strait KM, et al. Perceived stress after acute myocardial infarction: a comparison between young and middle-aged women versus men. Psychosom Med. 2017;79(1):50-58.

28. Smolderen KG, Buchanan DM, Gosch K, et al. Depression treatment and 1-year mortality after acute myocardial infarction: insights from the TRIUMPH Registry (Translational Research Investigating Underlying Disparities in Acute Myocardial Infarction Patients' Health Status). Circulation. 2017;135(18):1681-1689.

29. Choi J, Daskalopoulou SS, Thanassoulis G, et al. Sex- and genderrelated risk factor burden in patients with premature acute coronary syndrome. Can J Cardiol. 2014;30(1):109-117.

30. Leung Yinko SS, Pelletier R, Behlouli H, et al. Health-related quality of life in premature acute coronary syndrome: does patient sex or gender really matter? J Am Heart Assoc. 2014;3(4):e000901.

31. Park K, Wei J, Minissian M, Bairey Merz CN, Pepine CJ. Adverse pregnancy conditions, infertility, and future cardiovascular risk: implications for mother and child. Cardiovasc Drugs Ther. 2015;29(4):391-401.

32. Matthews KA, Santoro N, Lasley B, et al. Relation of cardiovascular risk factors in women approaching menopause to menstrual cycle characteristics and reproductive hormones in the follicular and luteal phases. J Clin Endocrinol Metab. 2006;91(5):1789-1795.

33. Grodstein F, Stampfer MJ, Colditz GA, et al. Postmenopausal hormone therapy and mortality. $N$ Engl J Med. 1997;336(25):1769-1775.

34. Schierbeck LL, Rejnmark L, Tofteng CL, et al. Effect of hormone replacement therapy on cardiovascular events in recently postmenopausal women: randomized trial. BMJ. 2012;345:e6409.

35. Rossouw JE, Anderson GL, Prentice RL, et al. Risks and benefits of estrogen plus progestin in healthy postmenopausal women: principal results from the women's health initiative randomized controlled trial. JAMA. 2002;288(3):321-333.

36. Hulley S, Grady D, Bush T, et al. Randomized trial of estrogen plus progestin for secondary prevention of coronary heart disease in postmenopausal women. Heart and Estrogen/progestin Replacement Study (HERS) Research Group. JAMA. 1998;280(7):605-613.

37. Viscoli CM, Brass LM, Kernan WN, et al. A clinical trial of estrogenreplacement therapy after ischemic stroke. N Engl J Med. 2001;345(17): 1243-1249.

38. Khan NA, Daskalopoulou SS, Karp I, et al. Sex differences in prodromal symptoms in acute coronary syndrome in patients aged 55 years or younger. Heart. 2017;103(11):863-869.

39. Rubini Gimenez M, Reiter M, Twerenbold R, et al. Sex-specific chest pain characteristics in the early diagnosis of acute myocardial infarction. JAMA Intern Med. 2014;174(2):241-249.

40. Eastwood JA, Johnson BD, Rutledge T, et al. Anginal symptoms, coronary artery disease, and adverse outcomes in Black and White women: the NHLBI-sponsored Women's Ischemia Syndrome Evaluation (WISE) study. J Women's Health. 2013;22(9):724-732.

41. Canto JG, Canto EA, Goldberg RJ. Time to standardize and broaden the criteria of acute coronary syndrome symptom presentations in women. Can J Cardiol. 2014;30(7):721-728.

42. Kreatsoulas C, Shannon HS, Giacomini M, Velianou JL, Anand SS. Reconstructing angina: cardiac symptoms are the same in women and men. JAMA Intern Med. 2013;173(9):829-831.

43. Devon HA, Rosenfeld A, Steffen AD, Daya M. Sensitivity, specificity, and sex differences in symptoms reported on the 13-item acute coronary syndrome checklist. J Am Heart Assoc. 2014;3(2):e000586.

44. Canto JG, Rogers WJ, Goldberg RJ, et al. Association of age and sex with myocardial infarction symptom presentation and in-hospital mortality. JAMA. 2012;307(8):813-822. 
45. Pelletier R, Humphries KH, Shimony A, et al. Sex-related differences in access to care among patients with premature acute coronary syndrome. CMAJ. 2014;186(7):497-504

46. Chandrasekhar J, Marley P, Allada C, et al. Symptom-to-Balloon Time is a Strong Predictor of Adverse Events Following Primary Percutaneous Coronary Intervention: results From the Australian Capital Territory PCI Registry. Heart Lung Circ. 2017;26(1):41-48.

47. Alshahrani H, McConkey R, Wilson J, Youssef M, Fitzsimons D. Female gender doubles pre-hospital delay times for patients experiencing ST segment elevation myocardial infarction in Saudi Arabia. Eur J Cardiovasc Nurs. 2014;13(5):399-407.

48. Lichtman JH, Leifheit-Limson EC, Watanabe E, et al. Symptom recognition and healthcare experiences of young women with acute myocardial infarction. Circ Cardiovasc Qual Outcomes. 2015;8(2 Suppl 1): S31-S38.

49. D’Onofrio G, Safdar B, Lichtman JH, et al. Sex differences in reperfusion in young patients with ST-segment-elevation myocardial infarction: results from the VIRGO study. Circulation. 2015;131(15): 1324-1332.

50. Mosca L, Mochari-Greenberger H, Dolor RJ, Newby LK, Robb KJ. Twelve-year follow-up of American women's awareness of cardiovascular disease risk and barriers to heart health. Circ Cardiovasc Qual Outcomes. 2010;3(2):120-127.

51. Falk E, Nakano M, Bentzon JF, Finn AV, Virmani R. Update on acute coronary syndromes: the pathologists' view. Eur Heart J. 2013; 34(10):719-728

52. Virmani R, Burke AP, Farb A. Sudden cardiac death. Cardiovasc Pathol. 2001;10(5):211-218.

53. White SJ, Newby AC, Johnson TW. Endothelial erosion of plaques as a substrate for coronary thrombosis. Thromb Haemost. 2016;115(3): 509-519.

54. Saia F, Komukai K, Capodanno D, et al. Eroded Versus Ruptured Plaques at the Culprit Site of STEMI: In Vivo Pathophysiological Features and Response to Primary PCI. JACC Cardiovasc Imaging. 2015;8(5):566-575.

55. Jia H, Abtahian F, Aguirre AD, et al. In vivo diagnosis of plaque erosion and calcified nodule in patients with acute coronary syndrome by intravascular optical coherence tomography. J Am Coll Cardiol. 2013; 62(19):1748-1758.

56. Chandrasekhar J, Mehran R. Sex-based differences in acute coronary syndromes: insights from invasive and noninvasive coronary technologies. JACC Cardiovasc Imaging. 2016;9(4):451-464.

57. Ten Haaf ME, Rijndertse M, Cheng JM, et al. Sex differences in plaque characteristics by intravascular imaging in patients with coronary artery disease. EuroIntervention. 2017;13(3):320-328.

58. Lansky AJ, Ng VG, Maehara A, et al. Gender and the extent of coronary atherosclerosis, plaque composition, and clinical outcomes in acute coronary syndromes. JACC Cardiovasc Imaging. 2012;5(3 Suppl): $\mathrm{S} 62-\mathrm{S} 72$.

59. Ho V, Chang S, Olivas R, Almacen C, Dimanlig M, Rodriguez H. A student paper: music in critical care setting for clients on mechanical ventilators: a student perspective. Dimens Crit Care Nurs. 2012; 31(6):318-321.

60. Khuddus MA, Pepine CJ, Handberg EM, et al. An intravascular ultrasound analysis in women experiencing chest pain in the absence of obstructive coronary artery disease: a substudy from the National Heart, Lung and Blood Institute-Sponsored Women's Ischemia Syndrome Evaluation (WISE). J Interv Cardiol. 2010;23(6): 511-519.

61. Reynolds HR, Srichai MB, Iqbal SN, et al. Mechanisms of myocardial infarction in women without angiographically obstructive coronary artery disease. Circulation. 2011;124(13):1414-1425.

62. Spatz ES, Curry LA, Masoudi FA, et al. The Variation in Recovery: Role of Gender on Outcomes of Young AMI Patients (VIRGO) Classification System: a taxonomy for young women with acute myocardial infarction. Circulation. 2015;132(18):1710-1718.
63. Sharaf B, Wood T, Shaw L, et al. Adverse outcomes among women presenting with signs and symptoms of ischemia and no obstructive coronary artery disease: findings from the National Heart, Lung, and Blood Institute-sponsored Women's Ischemia Syndrome Evaluation (WISE) angiographic core laboratory. Am Heart J. 2013;166(1):134-141.

64. Jespersen L, Hvelplund A, Abildstrom SZ, et al. Stable angina pectoris with no obstructive coronary artery disease is associated with increased risks of major adverse cardiovascular events. Eur Heart J. 2012;33(6): 734-744.

65. Vaccarino V, Badimon L, Corti R, et al. Presentation, management, and outcomes of ischemic heart disease in women. Nat Rev Cardiol. 2013; 10(9):508-518

66. Bairey Merz CN, Pepine CJ, Walsh MN, Fleg JL. Ischemia and No Obstructive Coronary Artery Disease (INOCA): developing evidencebased therapies and research agenda for the next decade. Circulation. 2017;135(11):1075-1092.

67. De Ferrari GM, Fox KA, White JA, et al. Outcomes among nonST-segment elevation acute coronary syndromes patients with no angiographically obstructive coronary artery disease: observations from 37,101 patients. Eur Heart J Acute Cardiovasc Care. 2014;3(1):37-45.

68. Pasupathy S, Tavella R, Beltrame JF. The What, When, Who, Why, How and Where of Myocardial Infarction With Non-Obstructive Coronary Arteries (MINOCA). Circ J. 2016;80(1):11-16.

69. Pizzi C, Xhyheri B, Costa GM, et al. Nonobstructive Versus Obstructive Coronary Artery Disease in Acute Coronary Syndrome: A MetaAnalysis. J Am Heart Assoc. 2016;5(12):e004185.

70. Johnston N, Jonelid B, Christersson C, et al. Effect of gender on patients with ST-elevation and non-ST-elevation myocardial infarction without obstructive coronary artery disease. Am J Cardiol. 2015; 115(12):1661-1666.

71. Hansen KW, Hvelplund A, Abildstrom SZ, et al. No gender differences in prognosis and preventive treatment in patients with AMI without significant stenoses. Eur J Prev Cardiol. 2012;19(4):746-754.

72. Chokshi NP, Iqbal SN, Berger RL, et al. Sex and race are associated with the absence of epicardial coronary artery obstructive disease at angiography in patients with acute coronary syndromes. Clin Cardiol. 2010;33(8):495-501.

73. Gehrie ER, Reynolds HR, Chen AY, et al. Characterization and outcomes of women and men with non-ST-segment elevation myocardial infarction and nonobstructive coronary artery disease: results from the Can Rapid Risk Stratification of Unstable Angina Patients Suppress Adverse Outcomes with Early Implementation of the ACC/AHA Guidelines (CRUSADE) quality improvement initiative. Am Heart $J$. 2009;158(4):688-694.

74. Sara JD, Widmer RJ, Matsuzawa Y, Lennon RJ, Lerman LO, Lerman A. Prevalence of coronary microvascular dysfunction among patients with chest pain and nonobstructive coronary artery disease. JACC Cardiovasc Interv. 2015;8(11):1445-1453.

75. Camici PG, Crea F. Coronary microvascular dysfunction. N Engl J Med. 2007;356(8):830-840.

76. Mekonnen G, Hayek SS, Mehta PK, et al. Circulating progenitor cells and coronary microvascular dysfunction: results from the NHLBIsponsored Women's Ischemia Syndrome Evaluation - Coronary Vascular Dysfunction Study (WISE-CVD). Atherosclerosis. 2016;253: 111-117.

77. Stern S, Bayes de Luna A. Coronary artery spasm: a 2009 update. Circulation. 2009;119(18):2531-2534.

78. Lee JH, Lee H, Bae MH, et al. Gender differences among Korean patients with coronary spasm. Korean Circ J. 2009;39(10):423-427.

79. Sun H, Mohri M, Shimokawa H, Usui M, Urakami L, Takeshita A. Coronary microvascular spasm causes myocardial ischemia in patients with vasospastic angina. J Am Coll Cardiol. 2002;39(5):847-851.

80. Kawana A, Takahashi J, Takagi Y, et al. Gender differences in the clinical characteristics and outcomes of patients with vasospastic angina-a report from the Japanese Coronary Spasm Association. Circ J. 2013;77(5):1267-1274. 
81. Saw J, Mancini GB, Humphries KH. Contemporary review on spontaneous coronary artery dissection. J Am Coll Cardiol. 2016;68(3): 297-312.

82. Saw J, Aymong E, Sedlak T, et al. Spontaneous coronary artery dissection: association with predisposing arteriopathies and precipitating stressors and cardiovascular outcomes. Circ Cardiovasc Interv. 2014; 7(5):645-655.

83. Tweet MS, Gulati R, Williamson EE, Vrtiska TJ, Hayes SN. Multimodality imaging for spontaneous coronary artery dissection in women. JACC Cardiovasc Imaging. 2016;9(4):436-450.

84. Tweet MS, Hayes SN, Pitta SR, et al. Clinical features, management, and prognosis of spontaneous coronary artery dissection. Circulation. 2012;126(5):579-588.

85. Liang JJ, Tweet MS, Hayes SE, Gulati R, Hayes SN. Prevalence and predictors of depression and anxiety among survivors of myocardial infarction due to spontaneous coronary artery dissection. J Cardiopulm Rehabil Prev. 2014;34(2):138-142.

86. Chou AY, Prakash R, Rajala J, et al. The first dedicated cardiac rehabilitation program for patients with spontaneous coronary artery dissection: description and initial results. Can J Cardiol. 2016;32(4):554-560.

87. Krittanawong C, Tweet MS, Hayes SE, et al. Usefulness of cardiac rehabilitation after spontaneous coronary artery dissection. Am J Cardiol. 2016;117(10):1604-1609.

88. Tweet MS, Hayes SN, Codsi E, Gulati R, Rose CH, Best PJM. Spontaneous coronary artery dissection associated with pregnancy. $\mathrm{J} \mathrm{Am}$ Coll Cardiol. 2017;70(4):426-435.

89. Templin C, Ghadri JR, Diekmann J, et al. Clinical Features and Outcomes of Takotsubo (Stress) Cardiomyopathy. N Engl J Med. 2015; 373(10):929-938

90. Wang Y, Xia L, Shen X, et al. A new insight into sudden cardiac death in young people: a systematic review of cases of Takotsubo cardiomyopathy. Medicine (Baltimore). 2015;94(32):e1174.

91. Rich-Edwards JW, Fraser A, Lawlor DA, Catov JM. Pregnancy characteristics and women's future cardiovascular health: an underused opportunity to improve women's health? Epidemiol Rev. 2014;36:57-70.

92. Redfors B, Angeras O, Ramunddal T, et al. Trends in Gender Differences in cardiac care and outcome after acute myocardial infarction in Western Sweden: a report from the Swedish Web System for Enhancement of Evidence-Based Care in Heart Disease Evaluated According to Recommended Therapies (SWEDEHEART). J Am Heart Assoc. 2015;4(7):e001995.

93. Udell JA, Koh M, Qiu F, et al. Outcomes of women and men with acute coronary syndrome treated with and without percutaneous coronary revascularization. J Am Heart Assoc. 2017;6(1):e004319.

94. Pelletier R, Khan NA, Cox J, et al. Sex versus gender-related characteristics: which predicts outcome after acute coronary syndrome in the young? J Am Coll Cardiol. 2016;67(2):127-135.

95. Rodriguez F, Foody JM, Wang Y, Lopez L. Young hispanic women experience higher in-hospital mortality following an acute myocardial infarction. J Am Heart Assoc. 2015;4(9):e002089.

96. Batchelor WB. Interaction effects of race/ethnicity and sex on outcomes after PCI: a subanalysis of the PLATINUM Diversity study. Presented at: SCAI May 12, 2017; New Orleans, LA.

97. Pelletier R, Choi J, Winters N, et al. Sex differences in clinical outcomes after premature acute coronary syndrome. Can J Cardiol. 2016; 32(12):1447-1453.

98. Dreyer RP, Ranasinghe I, Wang Y, et al. Sex differences in the rate, timing, and principal diagnoses of 30-day readmissions in younger patients with acute myocardial infarction. Circulation. 2015;132(3): $158-166$.

99. Dreyer RP, Dharmarajan K, Kennedy KF, et al. Sex differences in 1-year all-cause rehospitalization in patients after acute myocardial infarction: a prospective observational study. Circulation. 2017;135(6): 521-531.

100. Cho KI, Shin ES, Ann SH, et al. Gender differences in risk factors and clinical outcomes in young patients with acute myocardial infarction. J Epidemiol Community Health. 2016;70(11):1057-1064.
101. Gulati M, Shaw LJ, Bairey Merz CN. Myocardial ischemia in women: lessons from the NHLBI WISE study. Clin Cardiol. 2012; 35(3):141-148.

102. Landry M, Price J, Delos-Reyes F, Childerhose D, Harvey P. Barriers to intake assessment in women referred for cardiac rehabilitation. Can J Cardiol. 2016;32(4):S6.

103. McGrady A, McGinnis R, Badenhop D, Bentle M, Rajput M. Effects of depression and anxiety on adherence to cardiac rehabilitation. J Cardiopulm Rehabil Prev. 2009;29(6):358-364.

104. Beckie TM, Beckstead JW, Schocken DD, Evans ME, Fletcher GF. The effects of a tailored cardiac rehabilitation program on depressive symptoms in women: a randomized clinical trial. Int J Nurs Stud. 2011;48(1):3-12.

105. Rawstorn JC, Gant N, Meads A, Warren I, Maddison R. Remotely delivered exercise-based cardiac rehabilitation: design and content development of a Novel mHealth platform. JMIR Mhealth Uhealth. 2016;4(2):e57

106. Leung Yinko SS, Maheswaran J, Pelletier R, et al; GENESIS-PRAXY investigators. Sex differences in health behavior change after premature acute coronary syndrome. Am Heart J. 2015;170(2):242-248.

107. Minges KE, Strait KM, Owen N, et al. Gender differences in physical activity following acute myocardial infarction in adults: A prospective, observational study. Eur J Prev Cardiol. 2017;24(2):192-203.

108. Dreyer RP, Xu X, Zhang W, et al. Return to work after acute myocardial infarction: comparison between young women and men. Circ Cardiovasc Qual Outcomes. 2016;9(2 Supp1 1):S45-S52.

109. Bucholz EM, Strait KM, Dreyer RP, et al. Effect of low perceived social support on health outcomes in young patients with acute myocardial infarction: results from the VIRGO (Variation in Recovery: Role of Gender on Outcomes of Young AMI Patients) study. J Am Heart Assoc. 2014;3(5):e001252.

110. Lindau ST, Abramsohn EM, Bueno H, et al. Sexual activity and counseling in the first month after acute myocardial infarction among younger adults in the United States and Spain: a prospective, observational study. Circulation. 2014;130(25):2302-2309.

111. Lu Y, Zhou S, Dreyer RP, et al. Sex differences in lipid profiles and treatment utilization among young adults with acute myocardial infarction: Results from the VIRGO study. Am Heart J. 2017;183:74-84.

112. Beckman AL, Bucholz EM, Zhang W, et al. Sex differences in financial barriers and the relationship to recovery after acute myocardial infarction. J Am Heart Assoc. 2016;5(10):e003923.

113. Afshar M, Pilote L, Dufresne L, Engert JC, Thanassoulis G. Lipoprotein(a) interactions with low-density lipoprotein cholesterol and other cardiovascular risk factors in premature acute coronary syndrome (ACS). J Am Heart Assoc. 2016;5(4):e003012.

114. Leung Yinko SS, Maheswaran J, Pelletier R, et al. Sex differences in health behavior change after premature acute coronary syndrome. Am Heart J. 2015;170:242-248.

115. Leung Yinko SS, Pelletier R, Behlouli H, et al. Health-related quality of life in premature acute coronary syndrome: does patient sex or gender really matter? J Am Heart Assoc. 2014;3(4):e000901.

116. Khera S, Kolte D, Gupta T, et al. Temporal trends and sex differences in revascularization and outcomes of ST-segment elevation myocardial infarction in younger adults in the United States. J Am Coll Cardiol. 2015;66:1961-1972.

117. Epps KC, Holper EM, Selzer F, et al. Sex differences in outcomes following percutaneous coronary intervention according to age. Circ Cardiovasc Qual Outcomes. 2016;9(2 Supp1 1):S16-S25.

118. De Luca L, Marini M, Gonzini L, et al. Contemporary trends and age-specific sex differences in management and outcome for patients with ST-segment elevation myocardial infarction. J Am Heart Assoc. 2016;5(12):e004202.

119. Heer T, Hochadel M, Schmidt K, et al. Sex differences in percutaneous coronary intervention-insights from the coronary angiography and PCI registry of the German Society of Cardiology. J Am Heart Assoc. 2017;6(3):e004972. 
International Journal of Women's Health

Dovepress

\section{Publish your work in this journal}

The International Journal of Women's Health is an international, peerreviewed open-access journal publishing original research, reports, editorials, reviews and commentaries on all aspects of women's healthcare including gynecology, obstetrics, and breast cancer. The manuscript management system is completely online and includes Visit http://www.dovepress.com/testimonials.php to read real quotes from published authors.

Submit your manuscript here: http://www.dovepress.com/international-journal-of-womens-health-journal 